\title{
Multi-Criteria Assessment Approach for a Residential Building Retrofit in Norway
}

Xiangjie Chen ${ }^{1,4, *}, \mathrm{Ke} \mathrm{Qu}^{2}$, John Calautit ${ }^{2}$, Anandasivakumar Ekambaram ${ }^{3}$, Wei Lu ${ }^{4}$, Caroline Fox ${ }^{5}$, Guohui Gan ${ }^{2}$, Saffa Riffat ${ }^{2}$

${ }^{1}$ Centre for Renewable Energy Systems Technologies (CREST), Wolfson School of

Mechanical, Electrical and Manufacturing Engineering, Loughborough University, Leicestershire, LE11 3TU, UK

${ }^{2}$ Department of Architecture and Built Environment, the University of Nottingham, University Park, Nottingham, NG7 2RD, UK

\section{${ }^{3}$ SINTEF, Byggforsk Høgskoleringen 7B, 7034 Trondheim, Norway}

${ }^{4}$ Shanghai Key Laboratory of Multiphase Flow and Heat Transfer in Power Engineering based in School of Energy and Power Engineering, University of Shanghai for Science and Technology, Jungong Road No. 516, Shanghai, 200031, China

${ }^{5}$ School of Health Sciences, Institute of Mental Health, University of Nottingham, Jubilee Campus, Triumph Road, Nottingham, NG7 2TU, UK.

\section{*Contact : Xiangjie Chen; Email:xiangjie.chen@nottingham.ac.uk}

Abstract: This paper presents a multi-criteria assessment approach for a wide range of energy efficient measures and their combinations applied for a residential building retrofit in Norway. A number of passive, active and renewable energy efficient measures (EEMs) have been selected and defined. Based on the level of energy saving potentials, these EEMs have been combined into 18 retrofit combination packages (COMBs) and grouped into various retrofit levels (Moderate Retrofit-I, II, III and Extensive Retrofit). The annual primary energy consumptions (heating, hot water and electricity) for the proposed combination packages were simulated in IESVE building energy simulation software. This is then followed by two levels of assessments: i) the comprehensive assessments of the key retrofit priorities including primary energy reduction, global costs, payback period and the carbon emission reduction and ii) social assessment with the aim to represent various stakeholders' views on the selected COMBs using a metric of weighting factors. Based on this, a multi-criteria assessment approach featuring a novel ranking factor (EEES) taking into account of energy, economic, environmental and social 
aspects during retrofit process was adopted. This approach quantifies different stakeholders' perspectives on the proposed COMBs, which could enable various stakeholders' involvement in the retrofit decision making process. It was concluded that COMB 05 and 06, which include only 2-3 passive and active EEMs have been ranked and chosen as the most favourable retrofit solutions, with EEES value equalled to 25.6 from various stakeholders' perspectives. The impacts of changing renewable energy prices and PV generated feed-in tariff rates on the global costs, carbon reductions and primary energy consumptions of the proposed COMBs, which have rarely been analysed in literature, are numerically investigated in this research. Such renewable EEMs which are greatly recommended by the European Commission, are expected to gain further support from national level government renewable incentives. Therefore, it is envisaged that in the long term, Extensive Retrofits incorporating mostly renewable EEMs could become more affordable and cost effective.

Keywords: Building retrofit, cost-optimal analysis, carbon emission, social assessment, multi-criteria approach

\section{Introduction}

The Intergovernmental Panel on Climate Change (IPCC) reported that there has been an approximate $1.0^{\circ} \mathrm{C}$ global temperature rise, since the pre-industrial era due to human activities [1]. They claim that if the current trend continues, global temperatures will rise by additional $1.5^{\circ} \mathrm{C}$ between the year 2030 and 2052. The Eurobarometer report on climate change, which was published in September 2017, states that $74 \%$ of European Union citizens consider climate change as a very serious problem and $92 \%$ of European citizens consider it as a serious problem [2].

Johansson et al. [3] state that buildings are responsible for $30-40 \%$ of global carbon emissions and that there is a high potential for energy savings in the building sector. The International Energy Agency (IEA) points out that making improvements in the energy efficiency of the housing stock could play a significant role in mitigating climate change and achieving energy system objectives [4]. Reducing greenhouse gas emission by applying energy efficiency solutions in the building retrofit process have been widely studied as an effective method to tackle the global warming challenge. In order to achieve European Union's policy goals, the rate of retrofitting has to increase from its current levels of $0.5 \%-1.5 \%$ to around $2.5 \%-3 \%$ of the housing stock per year [5, 6]. Rosenow et al. [7] and Wilson et al. [8] state that up to 50\% of the energy used in households could be saved by implementing energy efficient retrofits and other measures depending on policies that support decision making in the households [6]. A significant reduction in energy consumption in the European Union can be achieved by upgrading existing European buildings, since the existing building stock has low efficiency [8]. 
Most existing research works are focused on the investigation of potential energy savings and the economic aspects of the selected conventional energy retrofit measures (related to building fabric retrofits [9-13]) in Northern [14-19] and Southern [20-22] parts of Europe. Ciulla et al. [11] investigated the energy saving and economic impact for two typical buildings in four Italian cities. However, only basic retrofit measures related to building fabric (insulation and window replacing) were considered in this study. Similarly, Nicolae and George-Vlad [23] applied life cycle and thermal performance assessment of three external wall insulation materials for a building retrofit in Galati, Romania. Historical buildings in Italy $[11,24]$ and Portugal [10] were renovated by using a cost-optimal method considering energy, environmental and economic impacts of selected retrofit packages. A historic wooden apartment in Estonia [14] has been upgraded with external wall insulation, energy efficient window, heat recovery and an air to water heat pump. The authors concluded that the cost optimal primary energy consumption of $250 \mathrm{kWh} /\left(\mathrm{m}^{2}\right.$ a) could be achieved in the case study historical wooden building. In the study of Ascione et al. [21, 25], a number of cost-optimal retrofit packages were defined by considering both limitless economic availability and limited budget for a hospital building in Italy. The optimized results indicated a reduction of primary energy consumption up to $67.9 \mathrm{kWh} /\left(\mathrm{m}^{2}\right.$ a) with global costs reduction of $24.5 \%$. Static and dynamic simulation models have been established for predicting pre and post retrofit energy consumptions of a historical building in Ireland [15]. The results showed that $55.6 \%$ energy reduction could be achieved using selected deep retrofit measures.

The promotion of on-site renewable energy utilization has also been widely considered by researchers, with the aim to achieve the strict energy saving targets (i.e. $40 \%$ greenhouse gases reduction by 2030) for the building sector set by Energy Performance of Building Directive (EPBD) [26]. Lopez and Frontini [27] conducted a historic building retrofitting project incorporating solar photovoltaics (PV) and a solar thermal system to improve energy performance and the level of comfort for 3 buildings in Switzerland. Eicker et al. [28, 29] performed a cost effectiveness analysis of 3 demo buildings in Italy, Portugal and the UK. The economic benefits and the primary energy consumption for various configurations of two renewable technoogies (solar PV and solar thermal collectors) were investigated parametrically. Evola et al. [30] investigated the integration of BIPV into a social housing project in Italy for 3 different cities (Milan, Rome, Catania). The effects of building orientation and the characteristics of three different types of PV modules and PV size and costs were considered. Combined heat and power (CHP) was adopted by Santoli et al. [31] for the integration of bioenergy production with the Bari airport refurbishment project. The study analysed three bioenergy production resources using discounted cash flow method. Hybrid system integration for historical building retrofit was performed by Basso et al. [32], which 
included six different combinations of CHP (combined heat and power), PV (photovoltaics), $\mathrm{PV} / \mathrm{T}$ (solar hybrid collectors), electric heat pumps, transcritical $\mathrm{CO}_{2}$ heat pumps and gas heat pumps. The optimal renewable to primary energy ratio was proposed by Sharafi et al. [33] with the aim to achieve the optimized algorithms between energy saving, net present value and carbon emission. Nizetic et al. [34] proposed various hybrid energy options (wind, solar PV, fuel cell, etc.) for the residential application of heat pump integrated cooling system for Mediterranean climatic conditions. The authors concluded that the heat pump with heat recovery system showed better energy efficiency compared with other solutions.

In general, the final retrofit solution is not always the case of selecting the most cost-effective combination measures with the highest energy saving and lowest carbon emissions. The decision making process for building retrofit can take into considerations the stakeholders' (designers, tenants, landlords, local government and policy makers) preferences, since stakeholders evaluate retrofitting processes differently according to their roles, experiences and needs. Stakeholder's satisfaction has gained increasing importance in measuring success of projects, in addition to the so-called the "iron" triangle: time, cost and quality. Construction related projects are not exceptional in this regard. Identifying stakeholders' preferences plays a pivotal role in devising suitable efforts to ensure stakeholder satisfaction [35]. It is therefore very crucial to establish a practical and user friendly multi-criteria assessment approach to capture various stakeholders' preferences on proposed combination measures, as this could greatly facilitate the final decision making process. The literature review shown in Table 1 highlights that most of the current research is only focused on the assessment of energy [10, 20, 23], carbon emission [10, 18] and cost [11, 18, 36-39]. Analysis taking into account stakeholders' preferences in the retrofit decision making process is restricted in the context of using matrix for the evaluations of different social aspects [36], without linking them with the relevant energy, economic and environmental analysis. Moreover, most of this research has concentrated solely on the impact of individual renewable energy sources (solar PV [27, 32] and solar thermal collector [37, 39]) on the energy saving potential. Research evaluating the impacts of integrating conventional retrofit measures with the renewable energy measures on the energy saving, economic, environmental and social benefits is hardly performed and therefore deserves more attention.

In this research work, a typical residential apartment constructed in 1990s in Oslo (Norway) has been selected as the case study building. The proposed research aims to bridge the current research gaps and propose the following key research methodologies: 1) based on European Union's building energy saving categories [36],18 retrofit combination packages (COMBs) incorporating different levels of passive, active and renewable EEMs are firstly classified and grouped in to four categories (minor retrofits, moderate retrofits, extensive retrofits and 
137 almost zero-energy building retrofits), which corresponds to energy consumption reduction in 138 the range of $0-30 \%, 30-60 \%, 60-90 \%$ and beyond. A key target of this research is to integrate 139 commercially available renewable energy measures (Ground Source Heat Pump, solar PV,

140 solar thermal collector) with conventional passive and active energy measures and investigate

141 the overall energy saving potentials, economic benefits and carbon reductions. Based on this,

142 a multi-criteria assessment energy, economic, environmental and social (EEES) ranking

143 factor has been adopted, as a complementary method to evaluate different stakeholders'

144 perspective on the proposed combination packages. The implementation of this multi-criteria

145 assessment approach will greatly facilitate the retrofit decision making process with ease and

146 wider engagement from various stakeholders. 2) with the renewable energy incentives

147 prompted by European Commission, the material and manufacturing costs of the renewable

148 energy products are expected to drop drastically in the future. The impacts of changing

149 renewable energy prices and PV generated feed in tariff rates on the global costs, carbon

150 reductions and primary energy consumptions, which have rarely been studied in literature, are

151 numerically investigated in this research. 
Table 1 Summary of the latest published literature related to cost-effectiveness, carbon emission and social impact analysis

\begin{tabular}{|c|c|c|c|c|c|c|c|c|}
\hline Reference & $\begin{array}{l}\text { Building } \\
\text { type }\end{array}$ & $\begin{array}{l}\text { Vintage } \\
\text { and } \\
\text { location of } \\
\text { building }\end{array}$ & $\begin{array}{l}\text { Selected energy } \\
\text { retrofit measures }\end{array}$ & $\begin{array}{l}\text { Optimization } \\
\text { approach }\end{array}$ & $\begin{array}{l}\text { Life cycle } \\
\text { analysis } \\
\text { parameters }\end{array}$ & $\begin{array}{lr}\text { Carbon } & \text { emission } \\
\text { analysis } & \text { (équivalant } \\
\text { carbon } & \text { emission } \\
\text { factor) } & \end{array}$ & $\begin{array}{l}\text { Social } \\
\text { impact } \\
\text { analysis }\end{array}$ & Conclusion \\
\hline $\begin{array}{ll}\text { Liu et } & \text { et } \\
\text { al.[18] } & \end{array}$ & $\begin{array}{l}\text { Residential } \\
\text { apartment } \\
\text { building }\end{array}$ & $\begin{array}{l}\text { 1890s, } \\
\text { Stockholm, } \\
\text { Sweden }\end{array}$ & $\begin{array}{l}\text { Insulation (attic, } \\
\text { wall, basement), } \\
\text { glazing and heating } \\
\text { system upgrading }\end{array}$ & $\begin{array}{l}\text { Life cycle cost } \\
\text { method }\end{array}$ & $\begin{array}{l}\text { Discount rate: } \\
1 \%, 5 \%, 9 \%\end{array}$ & $\begin{array}{l}\text { District heating: } \\
0.124 \mathrm{tCO} 2 / \mathrm{MWh} \text {; } \\
\text { Electricity: } \\
0.74 \mathrm{tCO} 2 / \mathrm{MWh}\end{array}$ & NA & $\begin{array}{l}\text { The impact of the } \\
\text { variations of discount } \\
\text { rate was less important } \\
\text { compared with } \\
\text { changing electricity } \\
\text { price. }\end{array}$ \\
\hline $\begin{array}{l}\text { Sahin et } \\
\text { al. [20] }\end{array}$ & $\begin{array}{l}\text { Historical } \\
\text { hotel }\end{array}$ & $\begin{array}{l}1920 \mathrm{~s}, \\
\text { Izmir, } \\
\text { Turkey }\end{array}$ & $\begin{array}{l}\text { Insulation (attic, } \\
\text { wall, basement), } \\
\text { glazing and heating } \\
\text { system upgrading, } \\
\text { indoor temperature } \\
\text { control }\end{array}$ & $\begin{array}{l}\text { Transdisciplinary } \\
\text { approach }\end{array}$ & NA & NA & $\begin{array}{l}\text { Heritage } \\
\text { values, } \\
\text { durability, } \\
\text { moisture, } \\
\text { indoor } \\
\text { environment }\end{array}$ & $\begin{array}{l}\text { Considering the } \\
\text { preservation of } \\
\text { historical heritage, } \\
\text { about } 30 \% \text { of energy } \\
\text { saving could be } \\
\text { achieved. }\end{array}$ \\
\hline
\end{tabular}




\begin{tabular}{|c|c|c|c|c|c|c|c|c|}
\hline $\begin{array}{l}\text { Ciulla et } \\
\text { al. [11] }\end{array}$ & $\begin{array}{l}\text { Historical } \\
\text { building }\end{array}$ & $\begin{array}{l}\text { Cagliari/ } \\
\text { Roma/ } \\
\text { Milano/ } \\
\text { Palermo, } \\
\text { Italy }\end{array}$ & $\begin{array}{l}\text { Insulation } \quad \text { (roof, } \\
\text { external wall), } \\
\text { glazing upgrading, }\end{array}$ & $\begin{array}{l}\text { Cost-optimal } \\
\text { method }\end{array}$ & NA & NA & NA & $\begin{array}{l}\text { The primary energy } \\
\text { saving could reach } \\
44.6 \% \text { and } 56.7 \% \text { for } \\
\text { two building base } \\
\text { cases. }\end{array}$ \\
\hline $\begin{array}{l}\text { Tadeu et } \\
\text { al [10] }\end{array}$ & $\begin{array}{l}\text { Historical } \\
\text { building }\end{array}$ & $\begin{array}{l}\text { Beginning } \\
\text { of } \quad 20^{\text {th }} \\
\text { century, } \\
\text { Portugal }\end{array}$ & $\begin{array}{l}\text { Insulation (roof, } \\
\text { external wall), } \\
\text { glazing upgrading, } \\
\text { heating and domestic } \\
\text { hot water upgrading }\end{array}$ & $\begin{array}{l}\text { Cost-optimal } \\
\text { method }\end{array}$ & $\begin{array}{l}\text { Discount rate: } \\
6 \%, 12 \% \text {; Life } \\
\text { time: } 30 \text { years }\end{array}$ & $\begin{array}{l}\text { Natural gas: } \\
0.202 \mathrm{tCO} 2 / \mathrm{MWh} \\
\text { Electricity: } \\
\text { tCO2/MWh }\end{array}$ & NA & $\begin{array}{l}\text { The optimal insulation } \\
\text { thickness were } 50 \mathrm{~mm} \\
\text { to } 120 \mathrm{~mm} \text {, using } \\
\text { economic assessment. }\end{array}$ \\
\hline $\begin{array}{l}\text { Nicolae } \\
\text { and } \\
\text { George- } \\
\text { Vlad[23] }\end{array}$ & $\begin{array}{l}\text { School } \\
\text { building }\end{array}$ & $\begin{array}{l}\text { Galati, } \\
\text { Romania }\end{array}$ & $\begin{array}{lr}\text { Three } & \text { selected } \\
\text { external } & \text { wall } \\
\text { insulation materials }\end{array}$ & $\begin{array}{l}\text { Cost-optimal } \\
\text { method }\end{array}$ & NA & NA & NA & $\begin{array}{l}\text { The selected external } \\
\text { insulation retrofit } \\
\text { could lead to } 55 \% \text { less } \\
\text { energy consumption } \\
\text { compared with } \\
\text { baseline case. }\end{array}$ \\
\hline $\begin{array}{l}\text { Shao et al. } \\
{[37]}\end{array}$ & $\begin{array}{l}\text { Office } \\
\text { building }\end{array}$ & $\begin{array}{l}\text { 1900, } \\
\text { Aachen, } \\
\text { Germany }\end{array}$ & $\begin{array}{l}\text { Insulation } \\
\text { (basement, wall), } \\
\text { glazing and heating } \\
\text { system upgrading, air }\end{array}$ & $\begin{array}{l}\text { Multi-objective } \\
\text { optimization }\end{array}$ & NA & NA & NA & $\begin{array}{l}\text { This multi-objective } \\
\text { optimization presented } \\
\text { a suitable research } \\
\text { method to consider the }\end{array}$ \\
\hline
\end{tabular}




\begin{tabular}{|c|c|c|c|c|c|c|c|c|}
\hline & & & $\begin{array}{l}\text { tightness } \\
\text { improvement }\end{array}$ & & & & & $\begin{array}{l}\text { stakeholder's } \\
\text { requirement during } \\
\text { building retrofits. }\end{array}$ \\
\hline $\begin{array}{l}\text { Araujo et } \\
\text { al. [38] }\end{array}$ & $\begin{array}{l}\text { Residential } \\
\text { building }\end{array}$ & $\begin{array}{l}\text { Northern } \\
\text { Portugal }\end{array}$ & $\begin{array}{l}\text { Insulation } \\
\text { (basement, wall), } \\
\text { glazing and heating } \\
\text { system upgrading, } \\
\text { shutter and curtain, } \\
\text { HVAC upgrading, } \\
\text { solar collector }\end{array}$ & $\begin{array}{l}\text { Cost } \\
\text { effectiveness } \\
\text { method }\end{array}$ & $\begin{array}{l}\text { Discount rate: } \\
1 \%-6 \% \text {; energy } \\
\text { price variation: } \\
\pm 3 \%\end{array}$ & NA & $\begin{array}{l}\text { Investment } \\
\text { willingness } \\
\text { of the } \\
\text { stakeholders. }\end{array}$ & $\begin{array}{l}\text { This analysis studied } \\
\text { and presented a cost- } \\
\text { benefit ratio, which } \\
\text { leads to the optimal } \\
\text { selection of energy } \\
\text { efficient solutions. }\end{array}$ \\
\hline $\begin{array}{l}\text { Arumagi } \\
\text { et al. [39] }\end{array}$ & $\begin{array}{l}\text { Historical } \\
\text { wooden } \\
\text { apartment }\end{array}$ & $\begin{array}{l}\text { 1920s, } \\
\text { Estonia }\end{array}$ & $\begin{array}{l}\text { Insulation (attic, } \\
\text { wall), glazing } \\
\text { upgrading, } \\
\text { ventilation with heat } \\
\text { recovery, air to water } \\
\text { heat pump }\end{array}$ & $\begin{array}{l}\text { Cost-optimal } \\
\text { method }\end{array}$ & $\begin{array}{l}\text { Discount rate: } \\
4 \% ; \quad \text { energy } \\
\text { price } \\
\text { escalation: } 3 \%\end{array}$ & $\mathrm{NA}$ & NA & $\begin{array}{l}\text { The economic analysis } \\
\text { showed that the } \\
\text { optimal PE of } \\
250 \mathrm{kWh} /\left(\mathrm{m}^{2} \mathrm{a}\right) \text { for the } \\
\text { selected wooden } \\
\text { historical building. }\end{array}$ \\
\hline $\begin{array}{l}\text { Niuemela } \\
\text { et al. [40] }\end{array}$ & $\begin{array}{l}\text { Residential } \\
\text { apartment } \\
\text { building }\end{array}$ & $\begin{array}{l}\text { Helsinki, } \\
\text { Finland }\end{array}$ & $\begin{array}{l}\text { Insulation (attic, } \\
\text { wall, basement), } \\
\text { glazing and heating } \\
\text { system upgrading, } \\
\text { PV, solar collector, } \\
\text { ventilation system }\end{array}$ & $\begin{array}{l}\text { Cost-optimal } \\
\text { method }\end{array}$ & $\begin{array}{l}\text { Discount rate: } \\
3 \% \text { energy price } \\
\text { escalation: } 2 \% \text {, } \\
\text { life cycle } \\
\text { period: } 30 \text { years }\end{array}$ & $\begin{array}{l}\text { Electricity: } \\
\text { 0.209tCO2/MWh; } \\
\text { CHP: } \\
0.183 \mathrm{tCO} 2 / \mathrm{MWh}\end{array}$ & NA & $\begin{array}{l}\text { Energy saving of } 90- \\
98 € / \mathrm{m}^{2}, \\
\text { energy } \\
\text { around } \\
930 \mathrm{kWh} / \mathrm{m}^{2}\end{array}$ \\
\hline
\end{tabular}




\section{Methodology}

The research methodology applied for the proposed work is illustrated in Figure 1. The retrofit process can be classified into 3 stages: pre-retrofit, retrofit design and post-retrofit stage. During the pre-retrofit stage, building survey and physical monitoring were conducted in order to define the existing baseline building conditions and energy utilization situations. Social analysis including the residents' survey and the examination of the local regulations was conducted. During this stage, various social aspects including the local government planning permission, landlord/residents' preference, affordability and willingness towards certain energy measures were summarized and used as input for the design stage. In the retrofit design stage, based on the survey results and energy utility situation, the building baseline model was established and validated in IESVE building energy simulation software. A retrofit technology library was established with the detailed technology specification and costs provided by the Rezbuild project technology providers [40]. This was used to define and apply the individual energy efficient measures (EEMs) and their combination packages into the baseline model to perform the energy performance assessment. The next step was to conduct a cost optimal assessment and carbon emission calculation. Based on this, an assessment approach using a novel energy, economic, environmental and social (EEES) ranking factor was developed and adopted. This provides numerical evaluations from multi-criteria perspectives for the proposed combination packages. In the post-retrofit stage, the physical monitoring and Return of Investment (RoI) calculation will be performed to demonstrate the economic, social and environmental benefits for the proposed building retrofit plan compared with the baseline scenario. The multi-criteria assessment approach could be used as good practice guideline for other building retrofit projects in the Scandinavian Region and beyond.

\subsection{Demo building survey}

This research is derived from EU Horizon 2020 funded project RezBuild [41], which aims to achieve fast and efficient building retrofits for selected three demo site buildings in Norway, Italy and Spain. The research presented in this paper will focus on the building retrofits for a residential apartment building (as shown in Figure 2) in Oslo, Norway. In urban areas, the number of apartment dwellings is significantly higher than the national average. Such residential apartment in Oslo region accounts for around 50\% of the settlement patterns [42]. Constructed in 1990s, this demo site building represents typical dwelling types in Norway that have been in service for more than 20 years and now urgently needs energy retrofit. The demo site building is located at the Bertramjordet condominium in Rosenholmveien (14km from Olso centre). The Bertramjordet complex consists of 4-5 storey apartment buildings and townhouses. The selected demo building is apartment block No.64 in this area, with a total floor area of 
37 living in this community are mainly low-income family and pensioners.

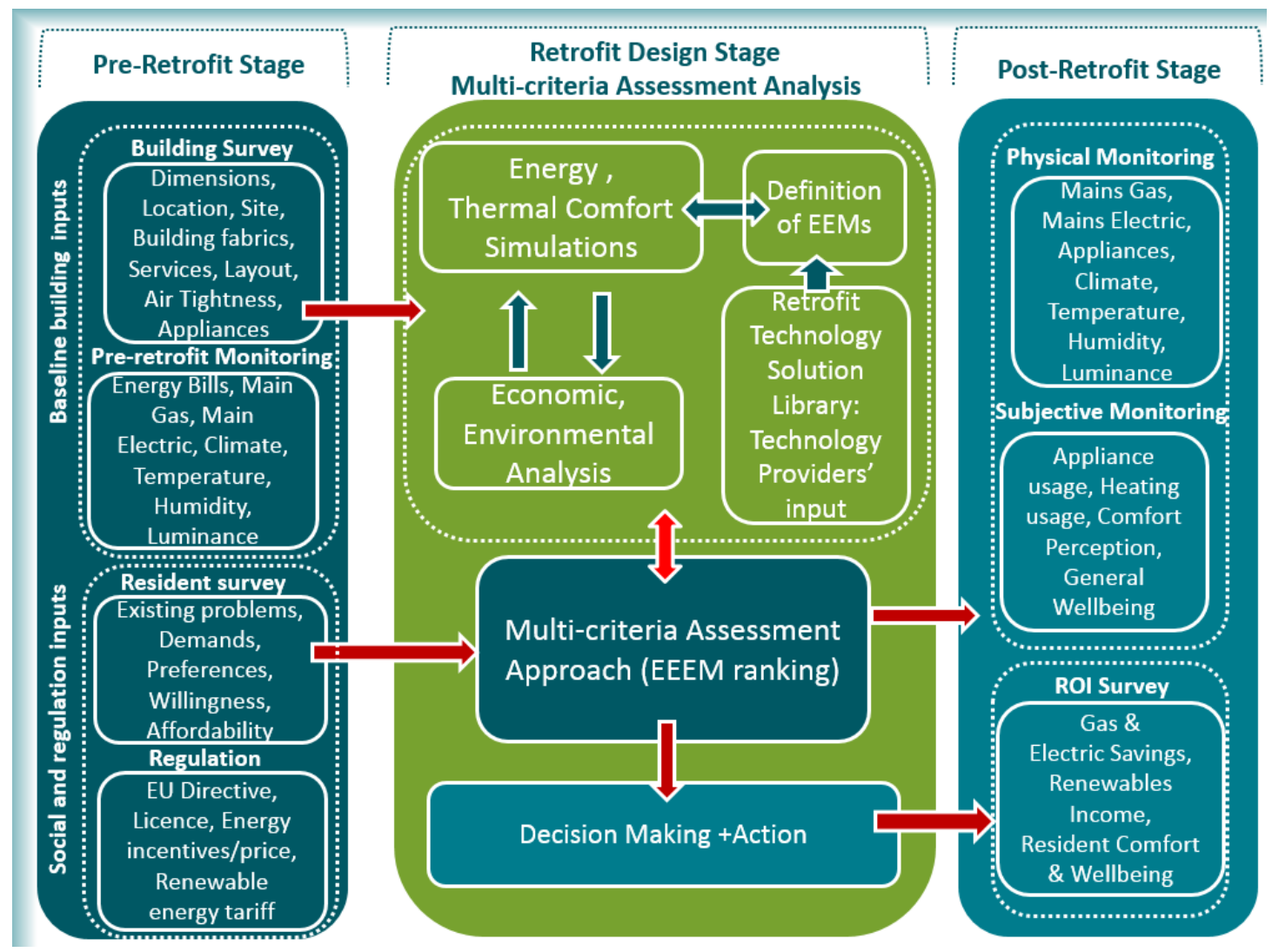

Figure 1 Schematic representation of the proposed research methodology

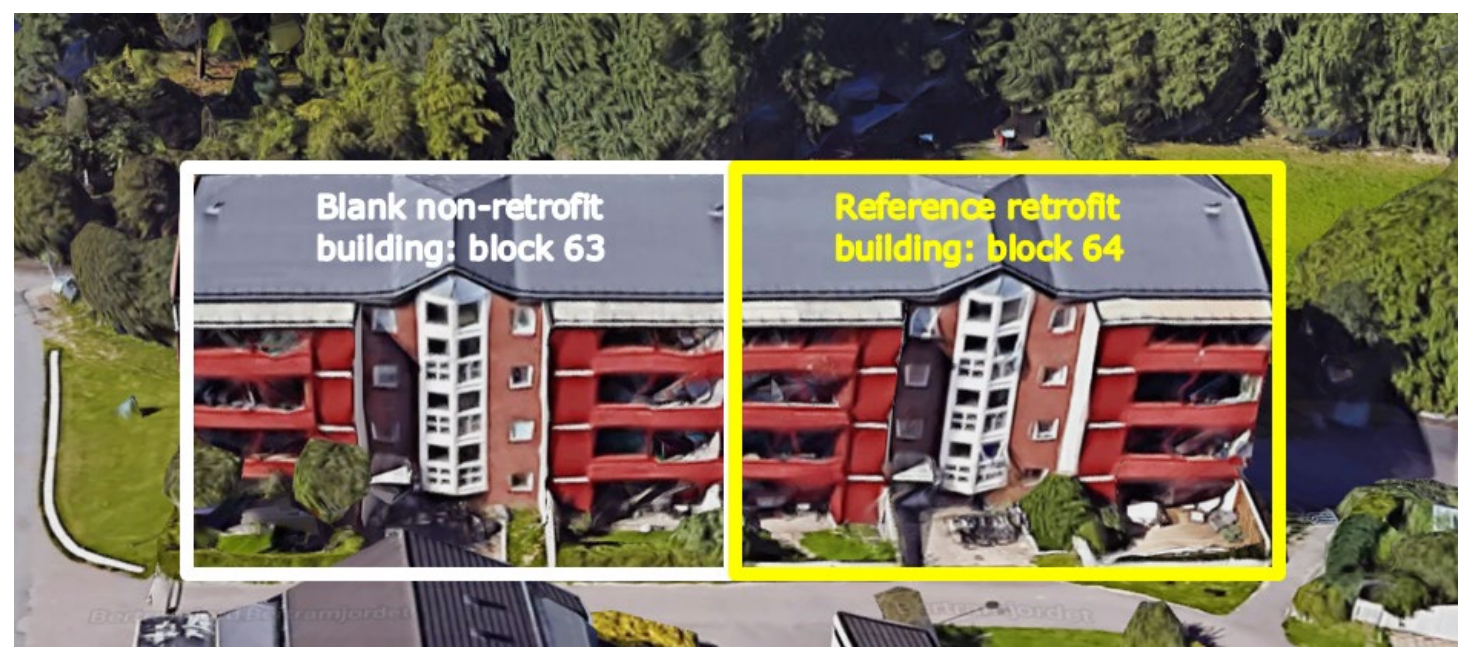

Figure 2 Southeast view of the demo site building

\subsection{Building condition characterization}

Building fabric conditions: Several site inspections, surveys and residents group meetings with the Bertramjordet cooperatives [43] were conducted by RezBuild project partner OBOS 
[44] from autumn 2016 to March 2017. The site survey showed that the external walls typically had a thickness of $280 \mathrm{~mm}$ with one layer of thermal insulation as detailed in Table 1 . The foundation was constructed of poured reinforced concrete with variable thickness. The attic floor consist of a mixture between mineral wool and reinforced concrete, each of $200 \mathrm{~mm}$ thickness. The detailed building characteristics and the $U$ values of building envelopes are listed in Table 1. The entire apartment building is connected with the district heating system, which generates heat by combustions of biomass wastes. The current district heating system in the baseline model was considered running $24-7$ at a constant room temperature of around $21^{\circ} \mathrm{C}$.

Occupancy behaviours: A pre-retrofit occupancy survey carried out by RezBuild project revealed that the current building occupancy is a mixture between retired pensioners and families with children. The occupancy profile was defined with the heating system on during the winter season (from $1^{\text {st }}$ September to $30^{\text {th }}$ May). The current heating system sometimes cause overheating problems to the residents, who kept the windows open for natural ventilation during winters. This will potentially leads to great amount of unnecessary heating energy consumption.

Table 1 Building characteristics and the $U$ value of building envelopes

\begin{tabular}{|l|l|l|l|}
\hline Building component & $\begin{array}{l}\text { Material (from outside to } \\
\text { inside) }\end{array}$ & $\begin{array}{l}\text { Total thickness } \\
(\mathrm{mm})\end{array}$ & $\begin{array}{l}\text { U-value } \\
\left(\mathrm{W} / \mathrm{m}^{2} \mathrm{~K}\right)\end{array}$ \\
\hline Roof & $\begin{array}{l}\text { concrete tiles, } \\
\text { fibreboard, membrane }\end{array}$ & 156 & 0.89 \\
\hline Attic Floor & mineral wool & 420 & 0.18 \\
\hline External gamble wall & reinforced concrete wall, \\
mineral wool & 280 & 0.32 \\
\hline External balcony wall & studwork wall, & & \\
\hline gypsum, mineral wool, & 160 & 0.23 \\
\hline Glazing & laths and horizontal cladding & & \\
\hline Basement floor & louble layer glazing & & 3.13 \\
\hline
\end{tabular}




\begin{tabular}{|l|l|l|l|}
\hline & $\begin{array}{l}\text { Urea-formaldehyde (UF) } \\
\text { foam, } \\
\text { Brickwork }\end{array}$ & & \\
\hline Basement ceiling & $\begin{array}{l}\text { lightweight metallic cladding, } \\
\text { steel, felt/bitumen layer }\end{array}$ & 15 & 5.98 \\
\hline Basement external wall & reinforced concrete wall & 280 & 3.43 \\
\hline
\end{tabular}

61

\subsection{Baseline model establishment}

Detailed energy modelling and performance assessment is crucial for accurately simulating the building energy consumption and saving potentials for selected energy measures, taking into account of the interactions between various parameters (building fabric details, climatic conditions, existing building service system). Hence, the demo building baseline model (as shown in Figure 3) was established in IESVE software. The available annual energy consumption bills for Bertramjordet condominium were used to validate the established model (Table 2). The baseline building simulation is carried out according to the following input parameters defined from ASHRAE and CIBSE guide: indoor temperature $\left(\geq 21^{\circ} \mathrm{C}\right)$; mechanical ventilation rate $(0.85 \mathrm{ACH})$; infiltration rate $(0.6 \mathrm{ACH})$; occupant internal gains $(90.0 \mathrm{~W} /$ person of sensible heat, $60.0 \mathrm{~W} /$ person of latent heat); lighting and electric device consumption $\left(4.4 \mathrm{~W} / \mathrm{m}^{2}\right)$; district heating efficiency $80 \%$; district heating mode (01 Sep to 31 May). For outdoor weather condition, the weather data of Oslo acquired from EnergyPlus is applied.

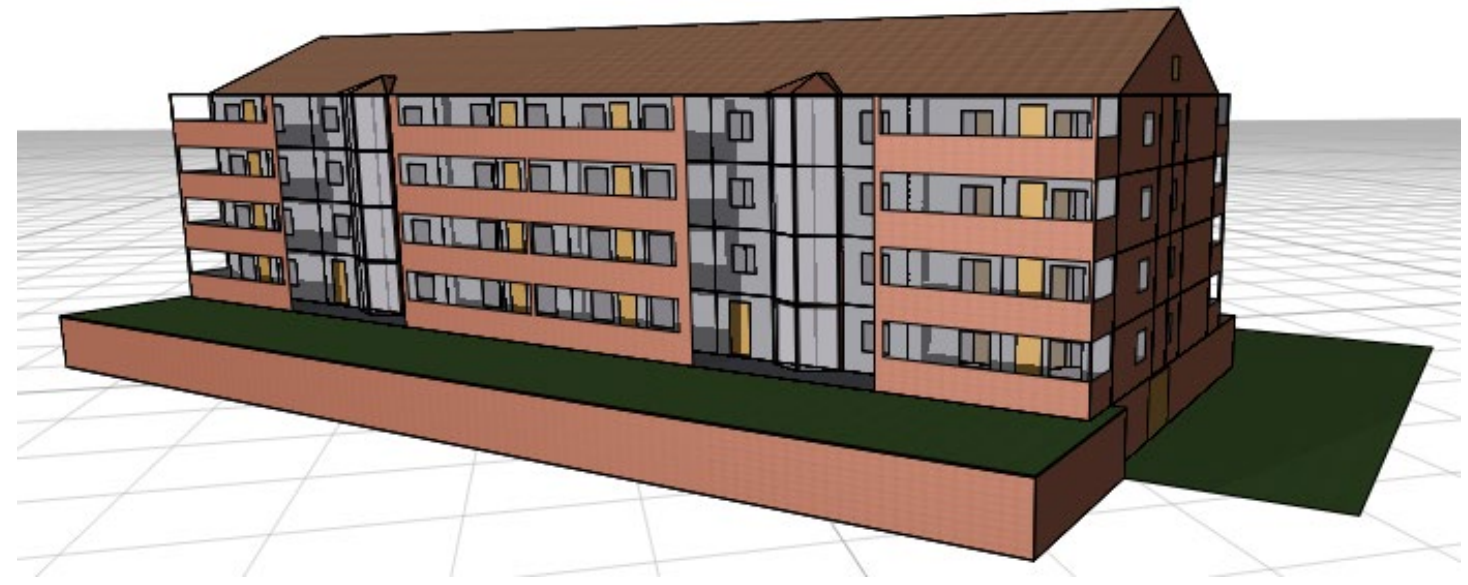

Figure 3 Baseline model of the demo site building in IESVE 


\begin{tabular}{|c|c|c|c|}
\hline & 2014 & 2015 & 2016 \\
\hline Annually monitored overall district heating energy $(\mathrm{kWh})$ & 118830 & 119682 & 125819 \\
\hline Annually monitored specific district heating energy $\left(\mathrm{kWh} / \mathrm{m}^{2}\right)$ & 127.2 & 128.1 & 134.7 \\
\hline Calculated district heating energy in building energy model $\left(\mathrm{kWh} / \mathrm{m}^{2}\right)$ & & & \\
\hline
\end{tabular}

80

\subsection{Energy performance assessment}

\subsubsection{Identification of individual energy efficient measures}

For the demo site building retrofit in Oslo, three levels of energy efficient measures (EEMs) are identified: passive, active and renewable energy EEMs.

- Passive EEMs are related to the retrofit measures made to the existing building fabric conditions, such as retrofits of external wall, upgrading the existing window, green roofs for increasing the building sustainability $[45,46]$.

- Active EEMs include upgrading the building service system and energy saving control strategies to reduce the energy consumption, such as installation of lighting sensors, efficient lighting system, improving the air tightness of the building and smart building management system for temperature/space heating/cooling control.

- Renewable EEMs covering the utilization of renewable energies including solar PV, solar thermal collector and ground source heat pump.

Based on the building survey results and the obtained baseline building energy consumption condition, 5 passive EEMs, 3 active EEMs and 3 renewable EEMs have been defined and with the technical specifications shown in Table 3. All the technical specifications and product costs were obtained from the RezBuild project partners (see website [47]), available product manufacturers or technology developers. The investment costs summarized in Table 2 include design, product manufacture, connections to the supplier and installation/commissioning, $24 \%$ of VAT tax have been considered as Norway standard tax rate.

Table 3 Individual energy efficient measures, the associated technical specifications and costs

\begin{tabular}{|l|l|l|l|l|l|l|}
\hline & Nomenclature & $\begin{array}{l}\text { Energy efficient } \\
\text { measures (EEMs) }\end{array}$ & $\begin{array}{l}\text { Technical } \\
\text { specification }\end{array}$ & $\begin{array}{l}\text { Investment } \\
\text { costs }\end{array}$ & $\begin{array}{l}\text { Maintenan } \\
\text { ce costs }\end{array}$ & $\begin{array}{l}\text { Replacem } \\
\text { ent costs }\end{array}$ \\
\hline $\begin{array}{l}\text { Passive } \\
\text { measures }\end{array}$ & GR & $\begin{array}{l}\text { Glazing retrofit- } \\
\text { triple glazing }\end{array}$ & $\begin{array}{l}\mathrm{U}=0.62 \mathrm{~W} / \mathrm{m}^{2} \mathrm{~K} \\
\text { Triple glazing } \\
\text { windows }\end{array}$ & $€ 282.5 / \mathrm{m}^{2}$ & NA & NA \\
\hline
\end{tabular}




\begin{tabular}{|c|c|c|c|c|c|c|}
\hline & GI & $\begin{array}{l}\text { Garage ceiling } \\
\text { insulation } \\
\text { upgrading }\end{array}$ & $\begin{array}{l}\mathrm{U}=0.1 \mathrm{~W} / \mathrm{m}^{2} \mathrm{~K} \\
\mathrm{~d}=50 \mathrm{~mm} \\
\text { Vacuum } \\
\text { insulation panel }\end{array}$ & $€ 203.4 / \mathrm{m}^{2}$ & NA & NA \\
\hline & AI & $\begin{array}{l}\text { Attic floor } \\
\text { insulation } \\
\text { upgrading }\end{array}$ & $\begin{array}{l}\mathrm{U}=0.1 \mathrm{~W} / \mathrm{m}^{2} \mathrm{~K} \\
\mathrm{~d}=50 \mathrm{~mm} \\
\text { Vacuum } \\
\text { insulation panel }\end{array}$ & $€ 203.4 / \mathrm{m}^{2}$ & NA & NA \\
\hline & WI & $\begin{array}{l}\text { Wall insulation } \\
\text { upgrading }\end{array}$ & $\begin{array}{l}\mathrm{U}=0.1 \mathrm{~W} / \mathrm{m}^{2} \mathrm{~K}, \\
\mathrm{~d}=50 \mathrm{~mm} \\
\text { Vacuum } \\
\text { insulation panel }\end{array}$ & $€ 310.8 / \mathrm{m}^{2}$ & NA & NA \\
\hline & AT & $\begin{array}{l}\text { Air tightness } \\
\text { improvement }\end{array}$ & $\begin{array}{ll}\begin{array}{l}\text { EPDM } \\
\text { system }\end{array} & \text { foil } \\
\end{array}$ & $€ 22.0 / \mathrm{m}^{2}$ & NA & NA \\
\hline \multirow[t]{3}{*}{$\begin{array}{l}\text { Active } \\
\text { measures }\end{array}$} & HR & $\begin{array}{l}\text { Heat recovery } \\
\text { system }\end{array}$ & $\begin{array}{l}\text { Effectiveness: } \\
86 \%\end{array}$ & $€ 42,375.0$ & NA & NA \\
\hline & SP & $\begin{array}{l}\text { Set point } \\
\text { temperature sensor }\end{array}$ & $\begin{array}{l}\text { Temperature set } \\
\text { decrease to } 21^{\circ} \mathrm{C} \\
\text { in winter }\end{array}$ & $€ 4,746.0$ & NA & NA \\
\hline & ED & $\begin{array}{l}\text { Efficient lighting } \\
\text { device }\end{array}$ & $\begin{array}{lr}\text { LED lighting } \\
\text { with } \quad 40 \% \\
\text { electricity } \\
\text { reduced }\end{array}$ & $€ 2,689.4$ & NA & NA \\
\hline \multirow[t]{3}{*}{$\begin{array}{l}\text { Renewable } \\
\text { energy } \\
\text { measures }\end{array}$} & GSHP & $\begin{array}{l}\text { Ground source heat } \\
\text { pump }\end{array}$ & $\begin{array}{l}\text { GMDW } 18 \text { plus: } \\
\text { heat capacity of } \\
18.7 \mathrm{~kW} \\
\text { Operation point: } \\
\text { B0/W50, COP: } \\
3.4\end{array}$ & $\begin{array}{l}€ 28,2500.0 \\
\text { component } \\
\text { costs }(30 \mathrm{~kW})+ \\
€ 21,244.0 \\
\text { installation } \\
\text { costs }+ \\
€ 12,204.0 \\
\text { Vertical } \\
\text { Borehole } \\
\text { construction } \\
\text { costs }\end{array}$ & $\begin{array}{l}0.6 \% \text { of } \\
\text { the } \\
\text { investmen } \\
\text { t costs } \\
{[40]}\end{array}$ & $\begin{array}{l}\text { Over } 30 \\
\text { years, } \\
\text { Replacem } \\
\text { ent } \\
\text { factor }=0.4 \\
1[48]\end{array}$ \\
\hline & ST & $\begin{array}{l}\text { Flat solar thermal } \\
\text { collector for DHW }\end{array}$ & $\begin{array}{l}\mathrm{A}=172.8 \mathrm{~m}^{2} \text {, Tilt } \\
\text { angle } 25^{\circ} \\
\text { Solar } \\
\text { generation heat } \\
\text { efficiency: } 47 \% \\
\text { Azimuth } 135^{\circ} \\
\text { (from the North) } \\
\text { Azimuth } 315^{\circ} \\
\text { (from the North) }\end{array}$ & $\begin{array}{l}€ 655.4 / \mathrm{m}^{2} \\
\text { including all } \\
\text { the } \\
\text { components } \\
\text { and } \\
\text { installation } \\
\text { costs }\end{array}$ & $\begin{array}{l}2 \% \text { of the } \\
\text { investmen } \\
t \text { costs }[40]\end{array}$ & $\begin{array}{l}\text { Over } 30 \\
\text { years, } \\
\text { Replacem } \\
\text { ent } \\
\text { factor }=0.4 \\
1[48]\end{array}$ \\
\hline & BIPV & $\begin{array}{l}\text { Building Integrated } \\
\text { Photovoltaics }\end{array}$ & $\begin{array}{ll}\mathrm{A}=192 \mathrm{~m}^{2}, & \text { Tilt } \\
\text { angle } & 25^{\circ}, \\
28.9 \mathrm{~kW} & \text { (test } \\
\text { standard) } \\
\text { Electricity } \\
\text { generation } \\
\text { efficiency: } 18.8 \% \\
\text { Azimuth } 135^{\circ} \\
\text { (from the North) } \\
\text { Azimuth } 315^{\circ} \\
\text { (from the North) }\end{array}$ & $\begin{array}{l}€ 299.5 / \mathrm{m}^{2} \\
\text { including all } \\
\text { the } \\
\text { components } \\
\text { and } \\
\text { installation } \\
\text { costs }\end{array}$ & $\begin{array}{l}2 \% \text { of the } \\
\text { investmen } \\
t \text { costs }[40]\end{array}$ & $\begin{array}{l}\text { Over } 30 \\
\text { years, } \\
\text { Replacem } \\
\text { ent } \\
\text { factor }=0.4 \\
1[48]\end{array}$ \\
\hline
\end{tabular}

103 Glazing (GR): Most of the existing windows in the demo site building are double glazing with 104 the average $\mathrm{U}$ value of $3.13 \mathrm{~W} /\left(\mathrm{m}^{2} \cdot \mathrm{K}\right)$. According to the Norwegian passive house standard 105 of TEK 17[49], the U-value of the windows including frames should be less than $0.8 \mathrm{~W} /\left(\mathrm{m}^{2}\right.$. $106 K$ ) for residential apartment. As suggested and agreed by the residents, a triple-glazing window with U-value of $0.62 \mathrm{~W} /\left(\mathrm{m}^{2} \cdot \mathrm{K}\right)$, is chosen for glazing retrofit. The selected glazing retrofit 
(GR) has a total thickness of $48 \mathrm{~mm}(8 \mathrm{~mm}$ glass $+10 \mathrm{~mm}$ air cavity $+10 \mathrm{~mm}$ glass $+10 \mathrm{~mm}$ air cavity $+10 \mathrm{~mm}$ glass) with visible light normal transmittance of 0.76 and g-value of 0.68 .

Insulation (GI/AI/WI): The demo site building envelope has good thermal insulation layers with an average U-value of $0.3 \mathrm{~W} /\left(\mathrm{m}^{2} \cdot \mathrm{K}\right)$. However, this value does not comply with the Norwegian passive house standard of TEK 17 [49], with the indication of less than $0.1 \mathrm{~W} /\left(\mathrm{m}^{2}\right.$. $K$ ) for residential building envelope. Advanced insulation materials of vacuum insulation panels (VIP) manufactured and provided by RezBuild project partner Saint-Gobain Ltd. is chosen as the additional insulation materials. VIP with thickness of $75 \mathrm{~mm}$ is chosen for the retrofit of garage ceiling (GI) and attic floor (AI), while the VIP with $80 \mathrm{~mm}$ and $55 \mathrm{~mm}$ thickness will be applied in balcony wall and external wall (WI) respectively.

Air tightness (AT): To comply with the 2013 Part L Building regulations [50] and TEK17 Norwegian passive house standard [49], the air infiltration rate should be less than $2.5 \mathrm{ACH}$ at 50 Pa pressure difference. Therefore, EPDM foil system from Castelein Sealants NV Company [51] is selected to reduce the air infiltration rate from $0.6 \mathrm{ACH}$ to $0.35 \mathrm{ACH}$.

Mechanical ventilation with heat recovery (HR): the existing ventilation systems rely on the extraction fans, with the measured air flow rates in kitchens and bathrooms of $30 \mathrm{~L} / \mathrm{s}$ and $15 \mathrm{~L} / \mathrm{s}$, respectively. A mechanical ventilation with heat recovery system (HR) will be incorporated as one of the active measures for the existing building service systems. With the installation of $\mathrm{HR}$, fresh air will be drawn in with exhaust fans passing through the heat exchanger, where the fresh air from the outside will be preheated by the exhausted air from the room. In this measure, HR is designed with $86 \%$ effectiveness of heat recovery.

Automatic temperature control system (TP): According to ASHARE standard [52] and passive house standard in Norway [49], the suggested maximum and minimum temperature and relative humidity range are $26^{\circ} \mathrm{C}, 20^{\circ} \mathrm{C}$ and $30-60 \%$ for residential building blocks. Therefore in this study, the indoor set temperature will be controlled by BOASH heating starter kit with constant indoor temperature of $21^{\circ} \mathrm{C}$ during winter heating seasons.

Efficient lighting (ED): The current demo site building is equipped mostly with compact fluorescent lighting (CFL) bulbs. However, with the advancement of efficient lighting technologies, LED lighting bulbs are 50\% more efficient than the CFL. Therefore, efficient dimming lighting will be adopted as one of the active measures, which can achieve a total of $40 \%$ lighting energy saving compared with existing CFL bulbs with $3 \%$ internal gain reduction.

Ground Source Heat Pump (GSHP): The existing district heating system driven by biomass waste heat has two obstacles. Firstly, over the years, the degradation of the pipelines has resulted in reduced overall heating performance. The upgrading and maintenance work is 
needed regularly to improve the energy supply efficiency. Secondly, the temperature condition of the existing DH could not be controlled and adjusted by the occupants. During the pre-site survey, the indoor overheating problem was observed which can only be solved by keeping the window open to allow natural ventilation. The associated energy lost could be significantly avoided by using a more energy efficient supply system such as GSHP. Due to the extreme cold winter condition in Norway, borehole GSHP will be selected. In this simulation, the chosen operation point of such GSHP is B0/W50 with COP of 3.4, the heat capacity of $18.7 \mathrm{KW}$ and power consumption of $5.5 \mathrm{KW}$ under test standard of EN14511 [53].

Solar thermal collector (ST): As obtained from baseline building simulation results, the domestic hot water demand accounts for $15 \%$ of the total energy consumption. Considering the daily hot water consumption of $57.6 \mathrm{~L} /$ per person and the available roof surface area, the solar thermal collector with a total surface area of $172.8 \mathrm{~m}^{2}$ is proposed.

Building intergraded photovoltaic (BIPV): Benefitting from a large pitched roof, the demo site building can be equipped with BIPV system. The monocrystalline silicon based BIPV will be manufactured and provided by RezBuild project partner ONYX Ltd. According to the climatic data in IESVE, the calculated peak electricity generation rate can reach $28.9 \mathrm{KW}$. The total installation area of PV panels is estimated to be around $192 \mathrm{~m}^{2}$ with a tilt angle of $25^{\circ}$.

\subsubsection{Identification of retrofit combination packages}

Based on the defined various possible EEMs, 18 retrofit combination packages (COMBs) incorporating different levels of passive, active and renewable EEMs are classified according to the four categories specified by EU policy document . These four categories are: minor retrofits, moderate retrofits, extensive retrofits and almost zero-energy building retrofits, which corresponds to energy consumption reduction in the range of $0-30 \%, 30-60 \%, 60-90 \%$ and beyond, respectively [36]. In the proposed research, Moderate Retrofit-I, II, III and Extensive retrofit have been defined according to level and primary energy reduction, as shown in Table 4. Moderate Retrofit-I (combination packages COMB 01-04) focus on integrating passive only EEMs into the baseline model. Moderate Retrofit-II (COMB 05-08) are dedicated to investigate the combination between the selected active EEMs and passive EEMs. Moderate Retrofit-III (COMB 09-12) includes 1 active EEMs with 1-2 renewable energy measure/passive measures. Finally, the combinations between passive EEMs, active EEMs and at least 2 renewable EEMs are grouped in Extensive retrofit (COMB 13-18).

Table 4 Combination packages based on different retrofit levels 


\begin{tabular}{|c|c|c|c|c|c|c|c|c|c|c|c|c|}
\hline \multirow[t]{2}{*}{$\begin{array}{l}\text { Retrofit } \\
\text { Level }\end{array}$} & \multirow{2}{*}{$\begin{array}{l}\text { Combination } \\
\text { package } \\
(\mathrm{COMB})\end{array}$} & \multicolumn{5}{|c|}{ Passive measures } & \multicolumn{3}{|c|}{$\begin{array}{l}\text { Active } \\
\text { measures }\end{array}$} & \multicolumn{3}{|c|}{$\begin{array}{l}\text { Renewable energy } \\
\text { measures }\end{array}$} \\
\hline & & GR & $\mathrm{Gl}$ & A & & AT & HR & SP & ED & GSHP & ST & BIPV \\
\hline \multirow{4}{*}{$\begin{array}{l}\text { Moderate } \\
\text { Retrofit-I }\end{array}$} & COMB01 & $\sqrt{ }$ & $\sqrt{ }$ & $\sqrt{ }$ & & & & & & & & \\
\hline & COMB02 & $\sqrt{ }$ & & & 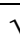 & & & & & & & \\
\hline & COMB03 & & $\sqrt{ }$ & $\sqrt{ }$ & 1 & & & & & & & \\
\hline & COMB04 & $\sqrt{ }$ & $\sqrt{ }$ & $\sqrt{ }$ & 1 & & & & & & & \\
\hline \multirow{4}{*}{$\begin{array}{l}\text { Moderate } \\
\text { Retrofit-II }\end{array}$} & COMB05 & $\sqrt{ }$ & & & & & $\sqrt{ }$ & & & & & \\
\hline & COMB06 & & & & & $\sqrt{ }$ & & $\sqrt{ }$ & $\sqrt{ }$ & & & \\
\hline & COMB07 & $\sqrt{ }$ & $\sqrt{ }$ & $\sqrt{ }$ & 1 & $\sqrt{ }$ & & $\sqrt{ }$ & $\sqrt{ }$ & & & \\
\hline & COMB08 & $\sqrt{ }$ & & & & $\sqrt{ }$ & $\sqrt{ }$ & $\sqrt{ }$ & & & & \\
\hline \multirow{4}{*}{$\begin{array}{l}\text { Moderate } \\
\text { Retrofit-III }\end{array}$} & COMB09 & $\sqrt{ }$ & & & & $\sqrt{ }$ & & $\sqrt{ }$ & & $\sqrt{ }$ & & \\
\hline & COMB10 & $\sqrt{ }$ & & & & & & & & $\sqrt{ }$ & & \\
\hline & COMB11 & & & & & & $\sqrt{ }$ & & & $\sqrt{ }$ & & \\
\hline & COMB12 & $\sqrt{ }$ & & & & & $\sqrt{ }$ & & & $\sqrt{ }$ & & \\
\hline \multirow{6}{*}{$\begin{array}{l}\text { Extensive } \\
\text { Retrofit }\end{array}$} & COMB13 & $\sqrt{ }$ & & & & & $\sqrt{ }$ & & & $\sqrt{ }$ & $\sqrt{ }$ & \\
\hline & COMB14 & $\sqrt{ }$ & & & & & $\sqrt{ }$ & & & $\sqrt{ }$ & $\sqrt{ }$ & $\sqrt{ }$ \\
\hline & COMB15 & $\sqrt{ }$ & & & & & $\sqrt{ }$ & & & $\sqrt{ }$ & & $\sqrt{ }$ \\
\hline & COMB16 & $\sqrt{ }$ & & & & $\sqrt{ }$ & $\sqrt{ }$ & $\sqrt{ }$ & & $\sqrt{ }$ & & \\
\hline & COMB17 & $\sqrt{ }$ & & & & $\sqrt{ }$ & $\sqrt{ }$ & $\sqrt{ }$ & & $\sqrt{ }$ & & $\sqrt{ }$ \\
\hline & COMB18 & $\sqrt{ }$ & $\sqrt{ }$ & $\sqrt{ }$ & 1 & $\sqrt{ }$ & $\sqrt{ }$ & $\sqrt{ }$ & $\sqrt{ }$ & $\sqrt{ }$ & $\sqrt{ }$ & $\sqrt{ }$ \\
\hline
\end{tabular}

2.3 Life cycle cost analysis and carbon emission calculation

177 As suggested by the European Directive on the energy performance in buildings (EPBD) [26],

178 the "cost optimal" method will be applied in this research to establish the relationship between 

the global costs and primary energy consumptions of the selected combination packages. The best optimal measures will be those with the highest levels of energy savings and lowest global costs. For the building sector, the total costs are defined as global costs $C_{g}(\tau)$, which takes in to account of the initial investment costs of selected EEMs and the accumulated annual costs over the life cycle period.

As a method for an economic assessment, the EPBD recast suggests the net present value (NPV) for the calculation of global costs [54]. An appropriate calculation can be described by the following formula:

$C_{g}(\tau)=C_{I}+\sum_{j}\left[\sum_{i=1}^{\tau}\left(C_{a, i}(j) \times R_{d}(i)\right)+C_{c, i}(j)-V_{f, \tau}(j)\right]$

Where

$C_{g}(\tau)$ is the global cost referring to starting year $\tau_{o}$;

$C_{I}$ is the initial investment costs;

$C_{a, i}(j)$ is the annual costs year I for energy related component $\mathrm{j}$, which includes energy costs, operational costs, periodic or replacement costs and maintenance costs;

$R_{d}(i)$ is discount rate for the year, which depends on the interest rate;

$C_{c, i}(j)$ is the accumulated carbon cost of greenhouse gas emissions due to the suggested technology measures over the life cycle period;

$V_{f, \tau}(j)$ is the final value of component $\mathrm{j}$ at the end of the calculation period (referred to the starting year $\tau_{o}$ ). The disposal cost (if applicable) should be considered here.

As the maintenance, operating and energy costs are all related to the expenses in the future, they will need to be calculated as present values according to the defined discount rate. The discount rate $R_{d}(i)$ depends on the real discount rate $R_{r}$, and the year (n) of the considered costs. The discount rate can be expressed as following:

$R_{d}(i)=\left(\frac{1}{1+R_{r}}\right)^{n}$

The real discount rate $R_{r}$ is closely related to market interest rate $\mathrm{R}$ and inflation rate $R_{i}$, can be calculated using following equation:

$R_{r}=\frac{R+R_{i}}{1+R_{i}}$

\subsubsection{Energy price, maintenance and operating costs}

As shown in Eq. (1), annual costs $C_{a, i}(j)$ include costs for energy carriers that cover the demand for space heating and cooling, ventilation, domestic hot water and lighting, including auxiliary 
energy. Income from produced energy (e.g. via photovoltaic systems) can be subtracted from

210 the costs for energy carriers. The service lifetime of measures should be set according to the

211 information set out in European standards (e.g. EN15459). The lifetime of the building elements

212 considered as following: thermal insulation (50 years), window and heat recovery system (30

213 years) and renewable energy sources (20 years).

214 According to the report from EPBD [48], residual value is considered only for thermal 215 protection measures (50 years lifetime period) with $40 \%$ value after 30 years of life cycle and 216 discounted to the beginning of the calculation period (16.5\% residual value for discount rate of $2173 \%$ ). The maintenance costs for BIPV, GSHP, ST, are considered as $0.6 \%, 3.0 \%$ and $2.0 \%$ of 218 their investment costs respectively [48]. The replacement costs were considered only for 219 technical installations of BIPV, GHSP and ST by the use of a replacement factor of 0.41 (3\% 220 discount rate) [48].

Table 5 Main parameter for the cost optimal analysis of the proposed research

\begin{tabular}{|l|l|}
\hline Calculation period & 30 years \\
\hline Country & Norway \\
\hline Electricity price & $€ 0.09 / \mathrm{kWh}$ \\
\hline District heating price & $€ 0.09 / \mathrm{kWh}$ \\
\hline Water usage price & $€ 0.005 /$ litre \\
\hline Market Interest Rate & $3.5 \%$ \\
\hline Inflation rate & $2.4 \%$ \\
\hline Energy price escalation rate & $2.8 \%$ for electricity and district heating [48] \\
\hline Maintenance costs & $\begin{array}{l}0.6 \%, 3 \% \text { and } 2 \% \text { of the initial investment } \\
\text { costs for BIPV, GSHP, ST }\end{array}$ \\
\hline Replacement factor & 0.41 \\
\hline Residual costs & $40 \%$ for thermal insulation layer only \\
\hline
\end{tabular}

222

\section{$223 \quad 2.5$ Carbon emission calculation}

224 As the global warming effect has posed serious threats to our climate, the environmental impact 225 especially the carbon emissions over the life cycle period should be considered and assessed 226 for the selected retrofit packages. The environmental impact associated with the generation of 227 the primary energy consumed (operation) and the utilization of renewable energies for 228 leveraging the carbon reduction are assessed. The primary energy consumption takes into 229 account of the overall primary energy requirement for heating, domestic hot water and 230 electricity consumption. Equivalent carbon emission factors are used to compare the emissions 231 from various greenhouse gases based upon their global warming potential (GWP) on a 100232 years' time frame.

233 The equivalent carbon emissions factors applied in this study are considered as follows: 
- District heating: $0.22 \mathrm{kgCO}_{2} \mathrm{eq} / \mathrm{kWh}$. As in Norway, the district heating system is mainly powered by waste incineration [55].

- Electricity: $0.18 \mathrm{kgCO}_{2} \mathrm{eq} / \mathrm{kWh}$, since the electricity is mainly generated by renewable hydropower in Norway [56].

- Solar thermal system and solar PV: $0.051 \mathrm{CO}_{2} \mathrm{eqkg} / \mathrm{kWh}$ and $0.13 \mathrm{kgCO} \mathrm{O}_{2 \mathrm{eq}} / \mathrm{kWh}$ respectively [57].

The accumulated carbon cost of the measures/packages over the life cycle period equals to the sum of the annual greenhouse gas emissions multiplied by the expected price per tones $\mathrm{CO} 2$ equivalent of greenhouse gas emission allowances in every year issued. Thus $C_{c, i}(j)$ can be calculated using the following equation:

$C_{c, i}(j)=\sum_{i=1}^{\tau}\left(C_{i}(j) * P_{j}\right)$

Where $C_{i}(j)$ is the annual greenhouse gas emission due to retrofit combination package $\mathrm{j} ; P_{j}$ is the expected price per tones $\mathrm{CO}_{2}$ equivalent of greenhouse gas emission allowances in every year issued. According to EU guideline [58], the momentary value of environmental damage for polluting emissions, in terms of cost per tonne of $\mathrm{CO}_{2}$ will be considered as $€ 20$ per tonne of $\mathrm{CO}_{2}$ equivalent until 2025, $€ 35$ until 2030 and $€ 50$ beyond 2030.

\section{Results and discussion}

\subsection{Primary energy consumption analysis}

Based on the simulations performed, the primary energy consumptions for the baseline building and the selected 18 retrofit combination packages are shown in Table 6. Compared with the primary energy consumption $\left(129.1 \mathrm{kWh} /\left(\mathrm{m}^{2}\right.\right.$ year $\left.)\right)$ of the baseline model, some of the selected combination packages could achieve very high energy consumption reduction, especially when the retrofit level improved from Moderate Retrofit towards Extensive Retrofit. For instance, about $55.6 \%$ of combination packages indicated primary energy consumption reaching less than $95 \mathrm{kWh} /\left(\mathrm{m}^{2}\right.$ year $)$, which was at least approaching the EPC standard class B according the Norwegian passive house standard [59]. The results of the simulation of Moderate Retrofit III and Extensive Retrofit indicated more than $45 \%$ primary energy reductions as compared with baseline condition. More detailed discussion will be presented combined with economic and carbon emission reduction in the following section. 
Table 6 Energy performances for the application of various retrofitting packages

\begin{tabular}{|c|c|c|c|c|c|c|}
\hline \multirow[t]{2}{*}{$\begin{array}{c}\text { Retrofit } \\
\text { level }\end{array}$} & $\begin{array}{c}\text { Combination } \\
\text { packages }\end{array}$ & $\begin{array}{l}\% \\
\text { reduction } \\
\text { compared } \\
\text { with } \\
\text { baseline } \\
\end{array}$ & $\begin{array}{c}\text { Energy } \\
\text { consumption } \\
\text { for heating } \\
E P_{h}\left(\mathbf{k W h} / \mathbf{m}^{2}\right. \\
\text { year) }\end{array}$ & $\begin{array}{c}\text { Energy } \\
\text { consumption } \\
\text { for domestic } \\
\text { hot water } \\
E P_{w}\left(\mathrm{kWh} / \mathrm{m}^{2}\right. \\
\text { year }) \\
\end{array}$ & $\begin{array}{c}\text { Energy } \\
\text { consumption for } \\
\text { electricity } E P_{e} \\
\left(\mathbf{k W h} / \mathbf{m}^{2} \text { year }\right)\end{array}$ & $\begin{array}{c}\begin{array}{c}\text { Primary } \\
\text { energy }\end{array} \\
\text { consumption } \\
\text { EP(kWh/m² } \\
\text { year) } \\
\end{array}$ \\
\hline & Baseline & & 123.1 & 26.0 & 42.5 & 171.6 \\
\hline \multirow[t]{4}{*}{$\begin{array}{l}\text { Moderate } \\
\text { Retrofit-I }\end{array}$} & COMB01 & $13.64 \%$ & 79.6 & 26.0 & 42.6 & 148.2 \\
\hline & COMB02 & $14.80 \%$ & 77.7 & 26.0 & 42.6 & 146.2 \\
\hline & COMB03 & $6.24 \%$ & 92.4 & 26.0 & 42.6 & 160.9 \\
\hline & COMB04 & $17.25 \%$ & 73.4 & 26.0 & 42.6 & 142.0 \\
\hline \multirow[t]{4}{*}{$\begin{array}{l}\text { Moderate } \\
\text { Retrofit-II }\end{array}$} & COMB05 & $22.26 \%$ & 62.6 & 26.0 & 44.8 & 133.4 \\
\hline & COMB06 & $24.71 \%$ & 73.0 & 26.0 & 30.2 & 129.2 \\
\hline & COMB07 & $40.21 \%$ & 46.5 & 26.0 & 30.2 & 102.6 \\
\hline & COMB08 & $39.45 \%$ & 33.1 & 26.0 & 44.8 & 103.9 \\
\hline \multirow[t]{4}{*}{$\begin{array}{l}\text { Moderate } \\
\text { Retrofit-III }\end{array}$} & COMB09 & $50.52 \%$ & 25.2 & 3.7 & 56.0 & 84.9 \\
\hline & COMB10 & $34.27 \%$ & 48.3 & 6.4 & 58.1 & 112.8 \\
\hline & COMB11 & $34.50 \%$ & 46.1 & 6.3 & 60.0 & 112.4 \\
\hline & COMB12 & $43.71 \%$ & 32.3 & 5.1 & 59.2 & 96.6 \\
\hline \multirow[t]{6}{*}{$\begin{array}{l}\text { Extensive } \\
\text { Retrofit }\end{array}$} & COMB13 & $50.82 \%$ & 29.0 & 0 & 55.5 & 84.4 \\
\hline & COMB14 & $57.98 \%$ & 29.0 & 0 & 43.2 & 72.1 \\
\hline & COMB15 & $57.23 \%$ & 32.3 & 5.1 & 36.0 & 73.4 \\
\hline & COMB16 & $57.93 \%$ & 12.5 & 2.5 & 57.2 & 72.2 \\
\hline & COMB17 & $71.45 \%$ & 12.5 & 2.5 & 34.0 & 49.0 \\
\hline & COMB18 & $83.10 \%$ & 0.3 & 0 & 28.8 & 29.0 \\
\hline
\end{tabular}

$266 \quad 3.2$ Cost-optimal and carbon emission analysis

267 Although critically important, the primary energy consumption cannot be treated as the only

268 benchmark for the retrofit decision making process. As discussed in section 2, cost-optimal

269 method has been applied in this research, taking into considerations of the investment costs,

270 energy costs, maintenance costs, replacement costs and residual costs of the building

271 components for the proposed various retrofit combination packages. The detailed investment

272 costs for the selected 18 combination packages have been illustrated in Figure 4. It can be seen

273 that the investment costs of "Moderate Retrofit-I" (COMB01-04) are more or less the same as 
in "Moderate Retrofit-III" (COMB09-12). The lowest investment costs are COMB 05 and 275 COMB06, which mainly include HR, SP, ED and AT. COMB 14-18 generally show the highest 276 investment costs, due to the high initial equipment costs for renewable EEMs.

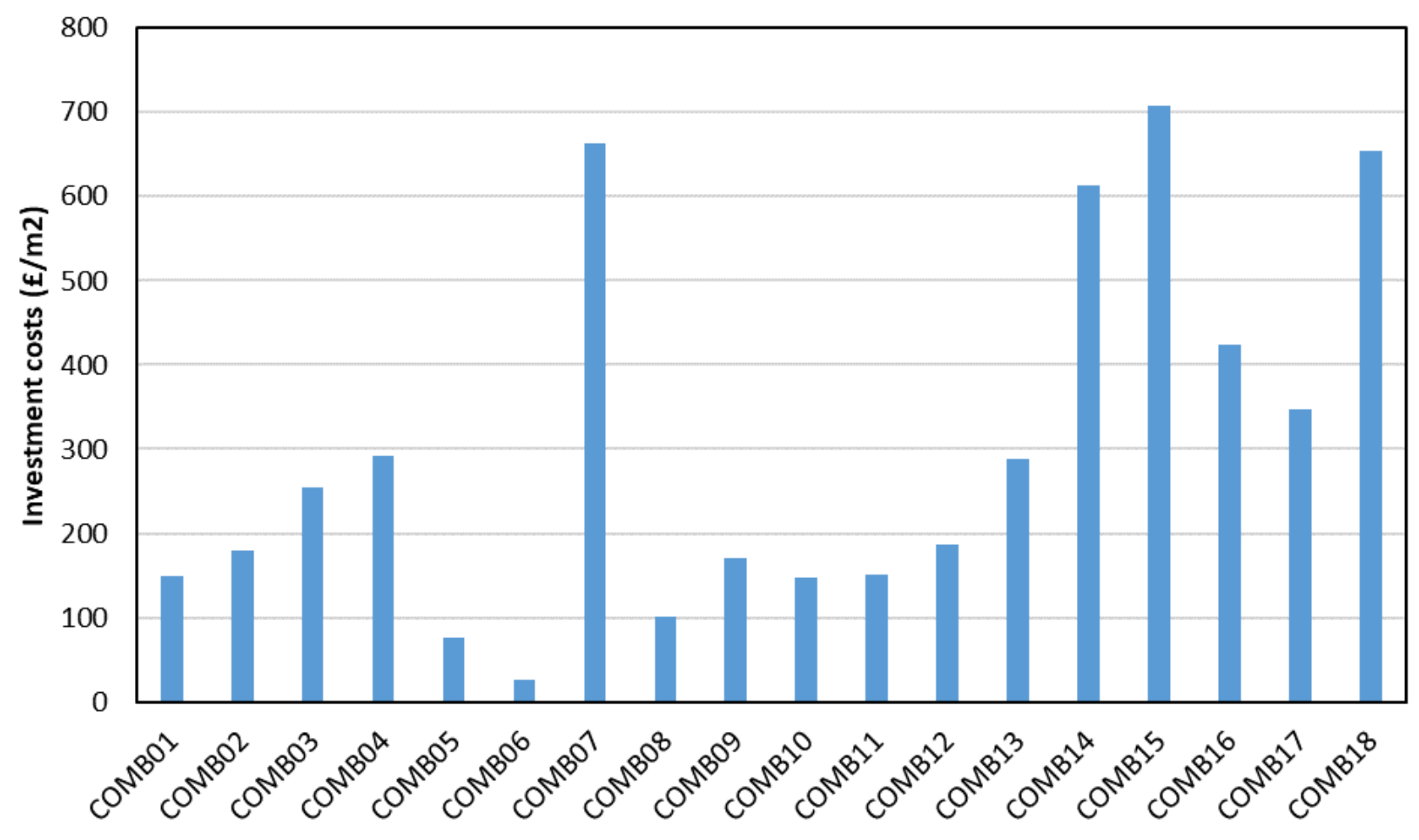

Figure 4 Investment costs for selected retrofitting combination packages

279 Applying the cost-optimal method, the detailed primary energy consumption, global costs, 280 payback period and carbon emissions for the 18 combination packages are presented in Table 281 7. The results were analysed and discussed in the following sections from the perspectives of return of investment, environmental impacts and sensitivity of renewable products prices. 
Table 7 Primary energy consumption, global costs, payback period and carbon emission for various retrofitting combination packages

\begin{tabular}{|c|c|c|c|c|c|}
\hline & $\begin{array}{l}\text { Primary energy } \\
\text { consumption } \\
\text { EP }\left(\mathrm{kWh} / \mathbf{m}^{2} \text { year }\right)\end{array}$ & $\begin{array}{l}\% \text { reduction } \\
\text { compared } \\
\text { with baseline } \\
\end{array}$ & $\begin{array}{l}\text { Global } \\
\operatorname{costs}\left(€ / \mathbf{m}^{2}\right)\end{array}$ & $\begin{array}{l}\text { Payback } \\
\text { period }\end{array}$ & $\begin{array}{l}\text { Equivalent } \\
\mathrm{CO2} \text { emission } \\
\left(\mathrm{KgCO} 2 / \mathrm{m}^{2}\right) \\
\end{array}$ \\
\hline \multicolumn{6}{|c|}{ Moderate Retrofit-I: only include passive measures } \\
\hline COMB01 & 148.2 & $13.64 \%$ & 270.2 & 42.7 & 30.9 \\
\hline COMB02 & 146.2 & $14.80 \%$ & 274.4 & 46.6 & 30.5 \\
\hline COMB03 & 160.9 & $6.24 \%$ & 306.4 & 142.3 & 33.7 \\
\hline COMB04 & 142.0 & $17.25 \%$ & 300.5 & 86.9 & 29.5 \\
\hline \multicolumn{6}{|c|}{ Moderate Retrofit-II: include both passive measures and active measures } \\
\hline COMB05 & 133.4 & $22.26 \%$ & 211.9 & 18.0 & 27.6 \\
\hline COMB06 & 129.2 & $24.71 \%$ & 216.4 & 5.4 & 27.2 \\
\hline COMB07 & 102.6 & $40.21 \%$ & 350.8 & 69.4 & 21.4 \\
\hline COMB08 & 103.9 & $39.45 \%$ & 208.0 & 13.3 & 21.1 \\
\hline \multicolumn{6}{|c|}{ Moderate Retrofit-III: include 1 renewable energy measure and other passive/active measures } \\
\hline COMB09 & 84.9 & $50.52 \%$ & 206.4 & 17.6 & 16.4 \\
\hline COMB10 & 112.8 & $34.27 \%$ & 262.6 & 22.4 & 22.5 \\
\hline COMB11 & 112.4 & $34.50 \%$ & 235.9 & 22.8 & 22.3 \\
\hline COMB12 & 96.6 & $43.71 \%$ & 227.3 & 22.4 & 18.9 \\
\hline \multicolumn{6}{|c|}{ Extensive Retrofit: include 2 renewable energy measures and other passive/active measures } \\
\hline COMB13 & 84.4 & $50.82 \%$ & 244.9 & 29.6 & 17.7 \\
\hline COMB14 & 72.1 & $57.98 \%$ & 306.4 & 44.8 & 19.3 \\
\hline COMB15 & 73.4 & $57.23 \%$ & 312.0 & 44.6 & 21.9 \\
\hline COMB16 & 72.2 & $57.93 \%$ & 274.0 & 38.2 & 13.6 \\
\hline COMB17 & 49.0 & $71.45 \%$ & 189.0 & 21.6 & 16.6 \\
\hline COMB18 & 29.0 & $83.10 \%$ & 278.5 & 38.0 & 10.4 \\
\hline
\end{tabular}

\subsubsection{Return of investment}

288 Figure 5 illustrates that COMB 05 and 06 yield the lowest global costs (around $210 € / \mathrm{m}^{2}$ ), but 289 the energy reduction compared with baseline case is only about $40 \mathrm{kWh} / \mathrm{m}^{2}$ year, which is 290 relatively high compared with other combination packages. By integrating 3-4 EEMs into the 291 combination packages, COMB 09-12 show the global costs to be in the range of $250-300 € / \mathrm{m}^{2}$, 292 which is about 1.2-1.4 times higher than COMB 05/06. The average energy reductions of 293 COMB09-12 are in the range of $84.9-112.8 \mathrm{kWh} / \mathrm{m}^{2}$ year, which is on average $35 \mathrm{kWh} / \mathrm{m}^{2}$ year 294 less compared with COMB 05/06. COMB 13-16 respectively integrated 1 passive, 1 active and 295 at least 2 renewable energy measures together. The addition of more renewable energy 296 measures demonstrates significant primary energy reduction (up to $100 \mathrm{kWh} / \mathrm{m}^{2}$ year compared 297 with baseline case). However, this has to be compensated by higher global costs. The global 298 costs for COMB13-16 are 300-450€/ $\mathrm{m}^{2}$, which are about 1.4-2.1 times higher than the lowest 299 value (COMB 05/06). Among all the Extensive Retrofits, COMB 17 offers the lowest global 


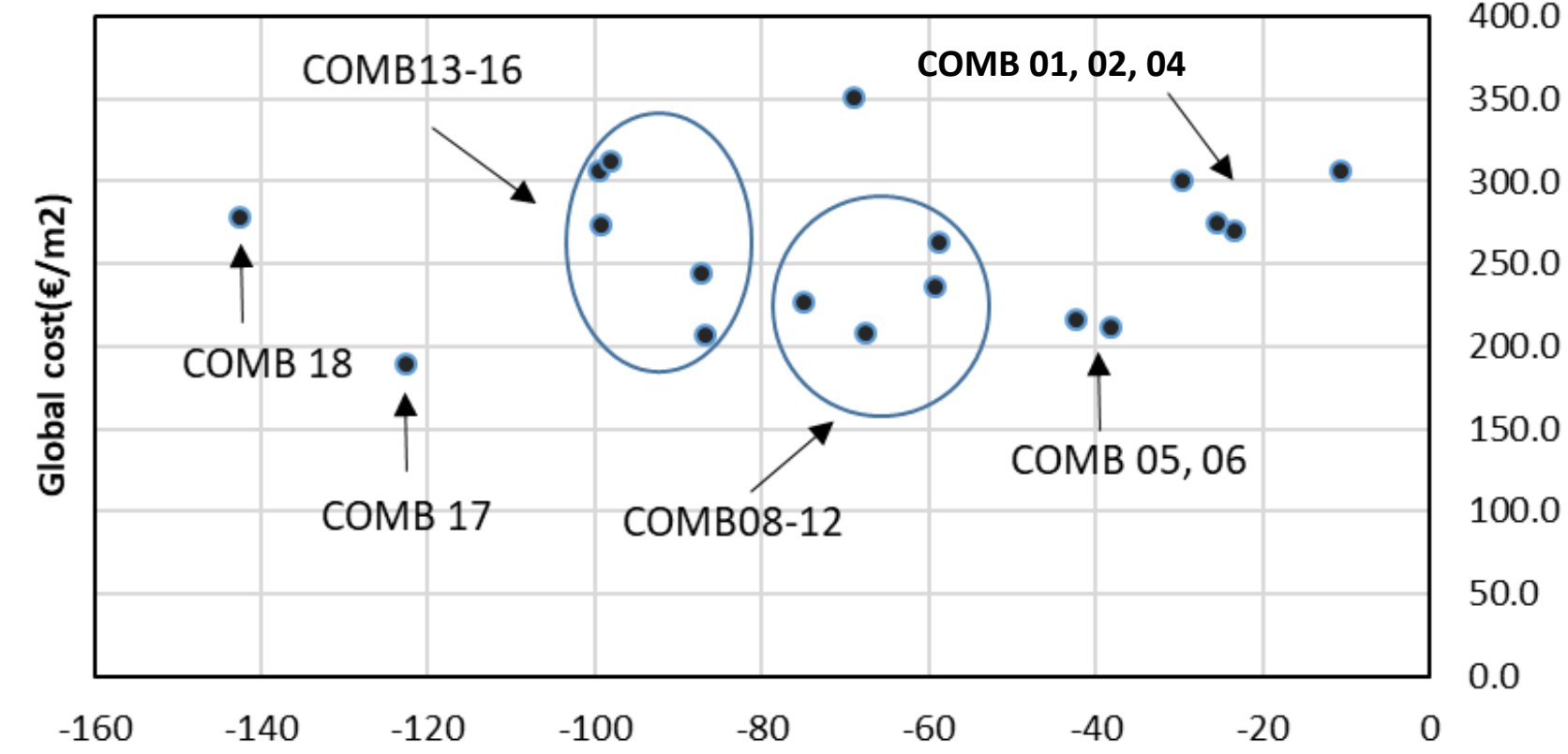
costs $\left(278.5 € / \mathrm{m}^{2}\right)$ with the primary energy reduction of $123 \mathrm{kWh} / \mathrm{m}^{2}$ year. COMB18 shows the highest final energy reduction (about $142 \mathrm{kWh} / \mathrm{m}^{2}$ year) with relatively reasonable global costs (around $278.5 € / \mathrm{m}^{2}$ ). It is possible to make different choices based on the available investment budget and the target primary energy reduction. If aiming for retrofitting with lowest investment costs, it would be practical to choose COMB 05/ 06. If the landlord is able to afford high investment costs with the aim to reduce the annual energy consumption, COMB 08, COMB912 could become attractive solutions.

Figure 5 illustrates that, in general, "Moderate Retrofit I" (COMB01-04) consumes more energy as compared with other combination packages. While the global costs for "Moderate Retrofit I" (COMB01-04) are within the medium level as compared with other 18 combination packages. This may be due to the fact that, the current baseline building has already been equipped with double-glazing and external insulation. Therefore, the further addition of insulation layers into the existing building fabric and the replacement of double-glazing with triple glazing makes very little difference to the primary energy consumption. It can be concluded that, for the specific baseline building, COMB01-04 would not be a cost-effective solution.

Figure 5 The variations of global costs with respect to final primary energy consumption reduction

Figure 6 illustrates the variations in payback periods with respect to primary energy consumption for the selected combination packages. With the integrations of passive and active 
consumption around $125 \mathrm{kWh} / \mathrm{m}^{2}$ year. COMB09-13 and COMB14-16 indicate similar payback

323 periods. Since COMB14-16 includes an additional renewable EEM than COMB09-13, the 324 primary energy consumption is about $27.8 \%$ less than the latter. COMB 17-18 have the lowest 325 primary energy consumption which is less than $35 \mathrm{kWh} / \mathrm{m}^{2}$ year than COMB 17-18, which 326 have relatively high payback periods (approximately 20-40 years).

327 In order to make it possible to compare the energy level of the proposed COMBs with other 328 houses, the energy performance certificate (EPC) standard has been applied. According to 329 regulation document PRNS3700 and TEK2017 official standard [49] [60], the overall energy 330 consumption should be less than $85 \mathrm{kWh} / \mathrm{m}^{2}$ year for class $\mathrm{A}$, followed by $95 \mathrm{kWh} / \mathrm{m}^{2}$ year, $331110 \mathrm{kWh} / \mathrm{m}^{2}$ year, $135 \mathrm{kWh} / \mathrm{m}^{2}$ year and $160 \mathrm{kWh} / \mathrm{m}^{2}$ year respectively for class B-E. The 332 detailed EPC classification has been included in Figure 6. It is obvious that the EPC level of 333 "Moderate Retrofit I" (COMB01-04) fall above class D and E, which do not satisfy the 334 Norwegian Passive House standard [49] with less than $120 \mathrm{kWh} / \mathrm{m}^{2}$ year annual primary energy 335 consumptions. Therefore, Moderate Retrofit I should be phased out.

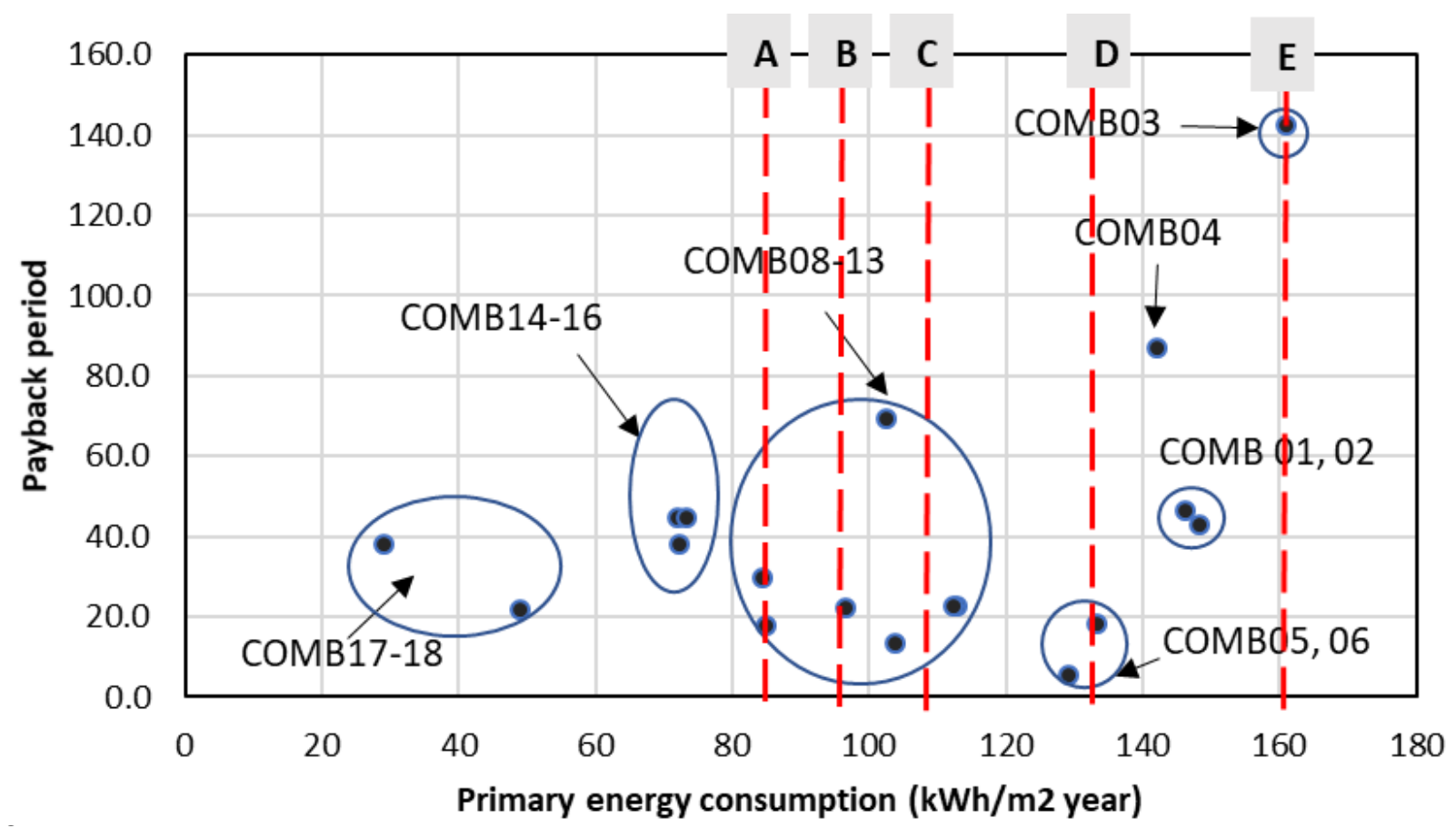

Figure 6 Variations of payback periods with respect to primary energy consumptions After eliminating COMB01-04, the remaining combination packages were evaluated based on the relationship between payback period and global costs and the results are shown in Figure 7. It can be seen that COMB05, 06, 08 and 17 represent the shortest payback period (below 20 341 years) with the global costs less than $220 € / \mathrm{m}^{2}$. COMB10,11, 12, 16 also yield relatively short 342 payback period (about 25-30 years). By integrating 3-4 EEMs together, COMB04, 07, 14, 15 
343 demonstrates relatively high initial investment costs, which lead to increased global costs (300-

$344350 \mathrm{kWh} / \mathrm{m}^{2}$ year).

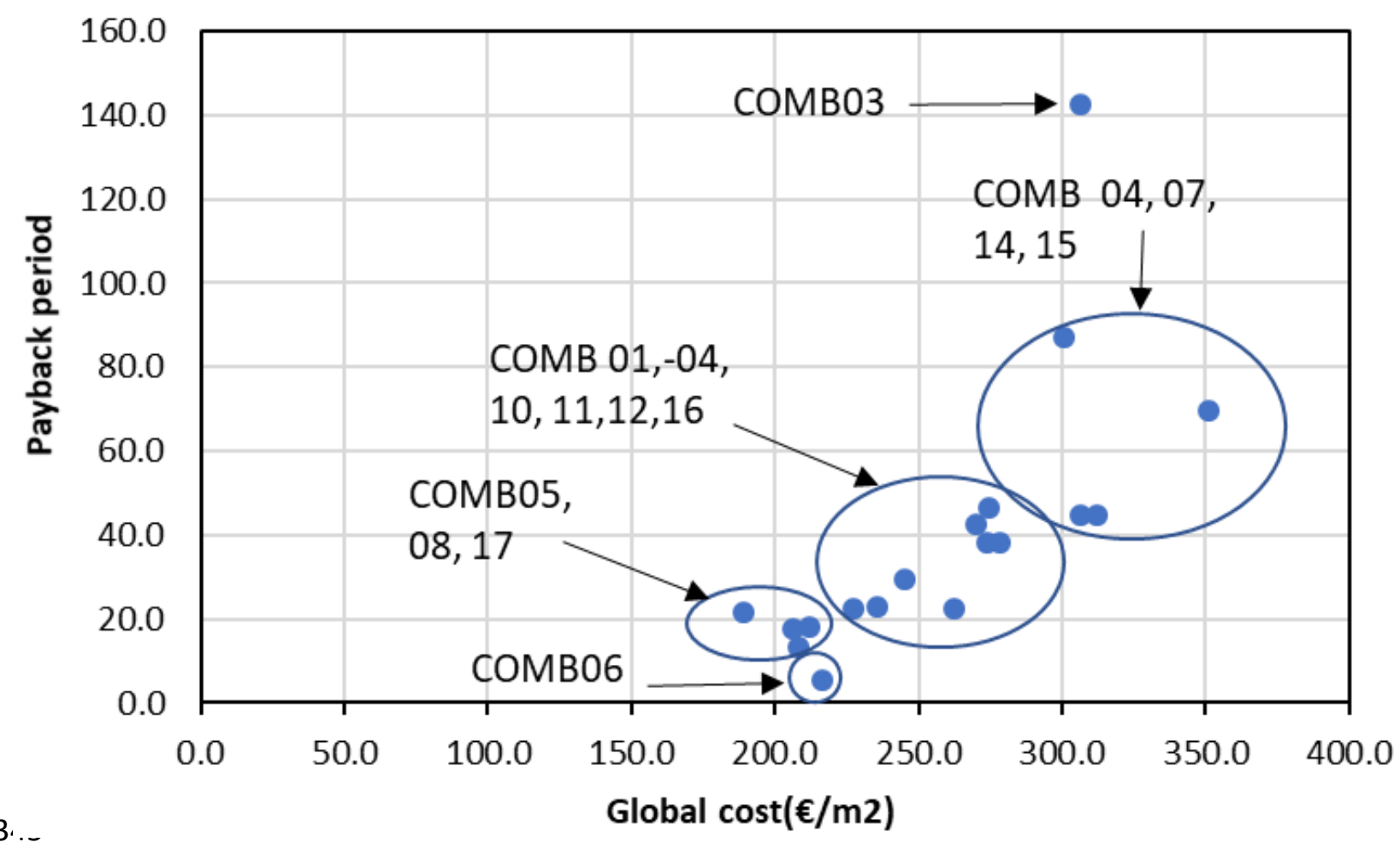

Figure 7 Variations of payback period with respect to global costs

\section{$347 \quad 3.2 .2$ Environmental impact}

348 Figure 8 illustrates the variations of equivalent $\mathrm{CO} 2$ emissions with respect to primary energy 349 consumptions, in combination with EPC standard classifications. Using the threshold of 130 $350 \mathrm{kWh} / \mathrm{m}^{2}$ year from Passive House standard, COMB01-05 should be phased out due to the high 351 primary energy consumption. COMB 07, 08, 10-12 could be classified under EPC standard 352 category $\mathrm{C}$ and $\mathrm{D}$, with the equivalent carbon emission between $15-25 \mathrm{kgCO}_{2} / \mathrm{m}^{2}$. Even though 353 there are similar primary energy consumption levels COMB14-16 show diversified equivalent 354 carbon emissions, in the range of $15-25 \mathrm{kgCO}_{2} / \mathrm{m}^{2}$. This is due to the fact that carbon emission 355 factor varies significantly for different renewable energy sources $\left(0.051 \mathrm{CO}_{2} \mathrm{~kg} / \mathrm{kWh}\right.$ for solar 356 thermal and $0.13 \mathrm{kgCO}_{2} / \mathrm{kWh}$ for solar $\mathrm{PV}$ ), which leads to different equivalent carbon 357 emissions. Integrating all the EEMs, COMB18 leads to the lowest primary energy consumption 358 and equivalent carbon emission. Further observation of Figure 8 indicates that COMB 09 and 35913 demonstrate approximately the same level of primary energy consumption and equivalent 360 carbon emission. It would therefore be interesting to further analyse these two combination 361 packages based on the global costs and payback period, as shown in Figure 8 and Figure 9. 


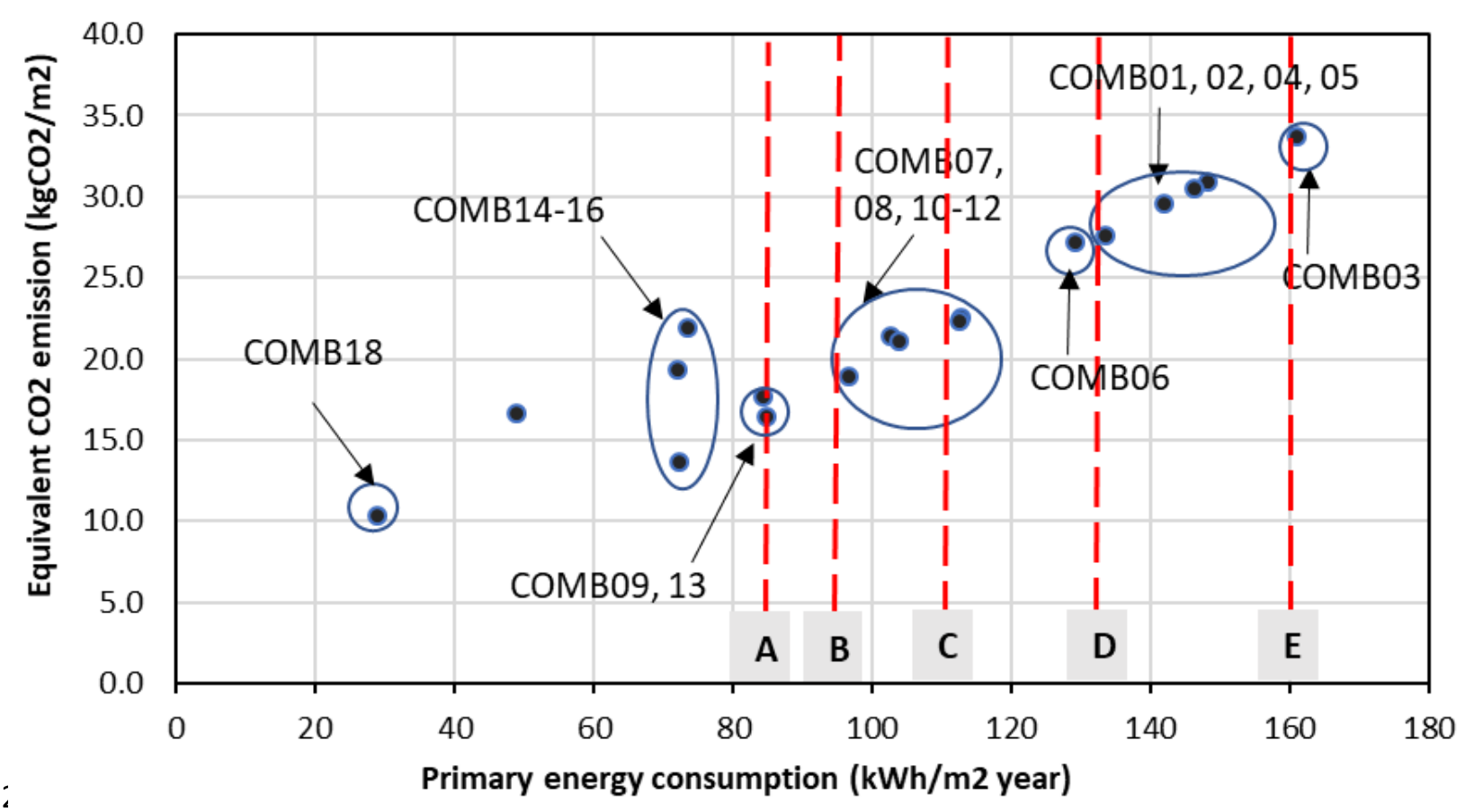

Figure 8 Variations of equivalent $\mathrm{CO} 2$ emissions with respect to primary energy consumptions

365 Figure 9 illustrates the variations of equivalent $\mathrm{CO}_{2}$ emissions with respect to global costs for 366 various combination packages. It could be noted that COMB17 yields the lowest global costs $367\left(189.0 € / \mathrm{m}^{2}\right)$ with equivalent $\mathrm{CO}_{2}$ emission equals to $16.6 \mathrm{kgCO}_{2} / \mathrm{m}^{2}$, followed by $\mathrm{COMB05}$ $368\left(211.9 € / \mathrm{m}^{2}\right)$ with equivalent $\mathrm{CO}_{2}$ emission of $27.6 \mathrm{kgCO} / \mathrm{m}^{2}$. With 3-4 EEMs included, 369 COMB14 and 15 show global costs around $300 € / \mathrm{m}^{2}$, which is about 1.4 times higher than 370 COMB 08-13. The average equivalent $\mathrm{CO}_{2}$ emission is in the range of $16.4-22.3 \mathrm{kWh} / \mathrm{m}^{2}$ year, 371 which are in the same level as COMB08-13. COMB18 indicates the lowest equivalent $\mathrm{CO}_{2}$ 372 emission with the global costs of $278.4 € / \mathrm{m}^{2}$. 


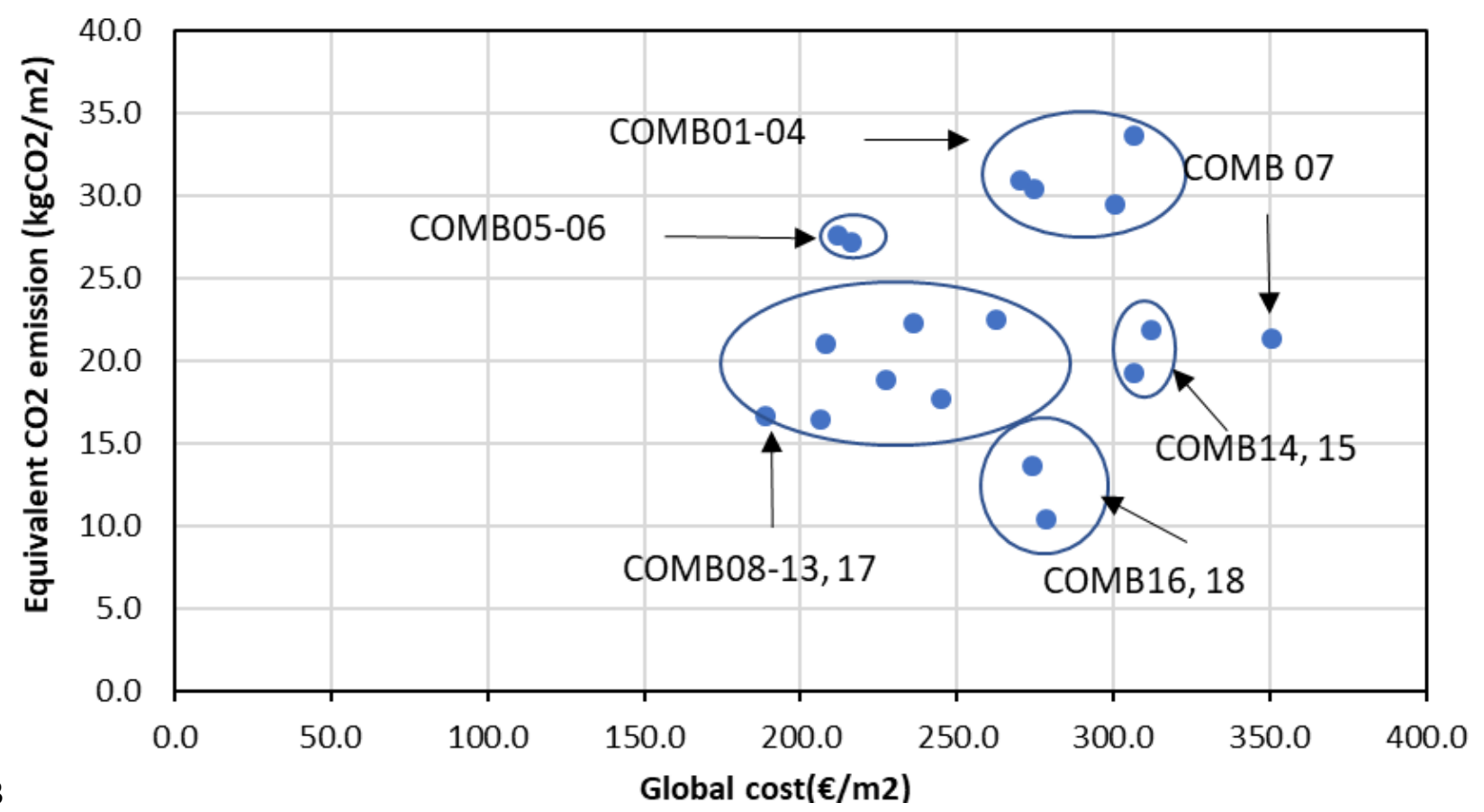

Figure 9 Variations of equivalent $\mathrm{CO}_{2}$ emissions with respect to global costs

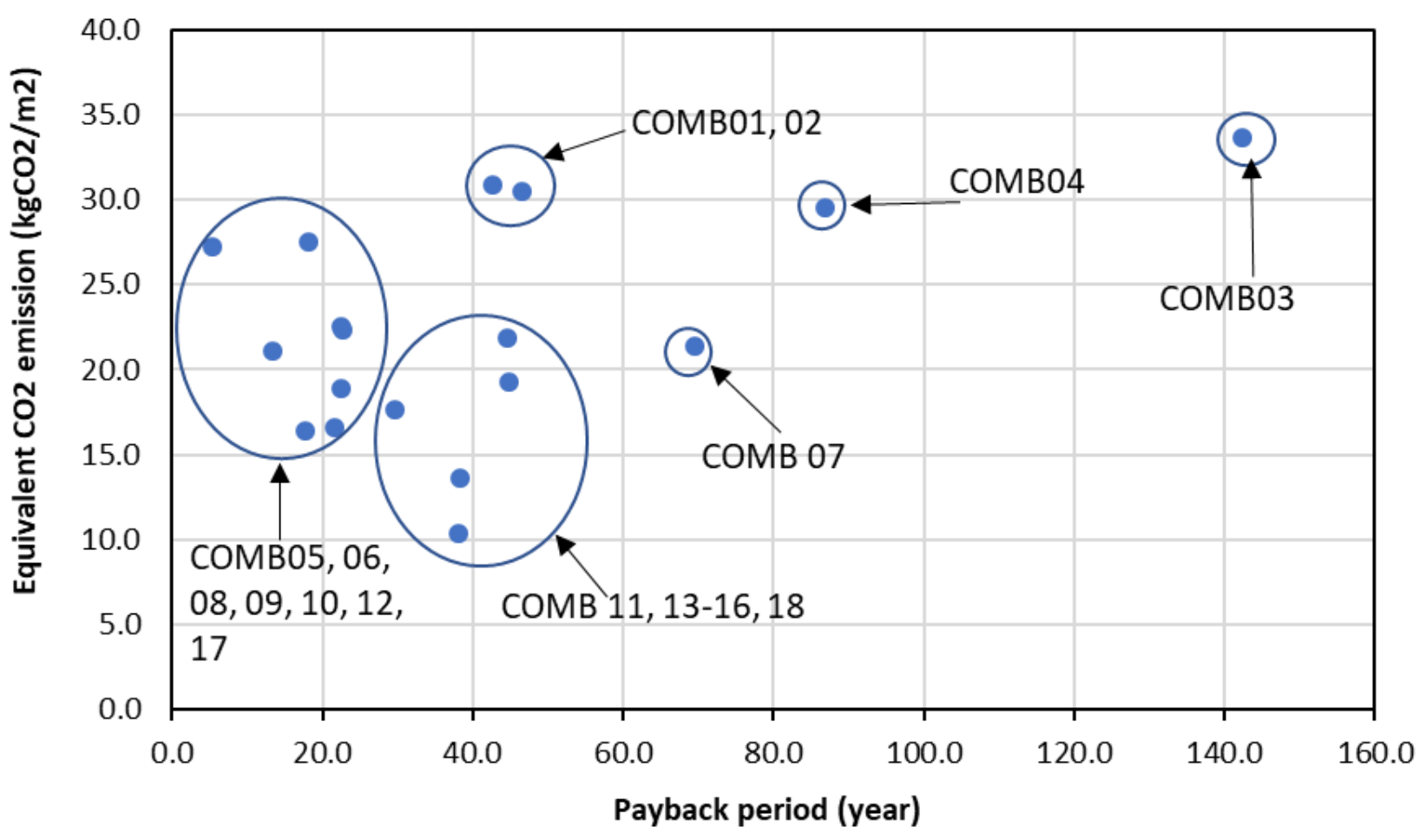

Figure 10 Variations of equivalent $\mathrm{CO}_{2}$ emissions with respect to payback periods

377 Figure 10 shows the variations of equivalent $\mathrm{CO}_{2}$ emission with respect to payback period for 378 the 18 COMBs. It can be found that in general, COMB 05, 06, 08-12 and 17 represent the 379 shortest payback period (less than 20 years) with equivalent $\mathrm{CO}_{2}$ emission averagely equals to $38022 \mathrm{kgCO}_{2} / \mathrm{m}^{2}$. Two groups of combination packages, including COMB11 and 13-16, 18 381 demonstrate the similar level of equivalent $\mathrm{CO}_{2}$ emission $\left(10.2-22.8 \mathrm{kgCO}_{2} / \mathrm{m}^{2}\right)$, and the 
payback period varies averagely from 30 to 40 years. It could be noted that although COMB1318 are all within Extensive Retrofit, COMB17 actually yields relatively shorter payback period (21.6 year) compared with COMB13-16,18 (38.0-44.8 years). The reason may be that COMB17 only incorporates 2 renewable EEMs with fully equipped BIPV, which generates significant amount of electricity, contributing greatly to the reduction of annual energy consumption.

\subsection{Sensitivity of renewable energy product prices}

Critical parameters including the market discount rate and interest rates are proven to have great impacts on the cost optimal analysis $[17,18,61]$. These parameters are affected drastically by the national economic development and the technology advancements over the years. Additionally, according to the EU renewable energy directive 2009[62], the EU is aiming at $20 \%$ less energy consumption with the utilization of renewable energy sources. In meeting this target, countries within EU have introduced various national incentives to facilitate the implementation of renewable energy [63]. Moreover, through technology development and advanced manufacturing techniques upgrading, the investment costs of renewable energy could be greatly reduced. However, the drop in renewable energy investment costs have not been considered in other research studies. This study shows that the sensitivity of renewable energy price has been moderately reduced by 3\%, 5\% and 7\% respectively. Considering the government incentives to encourage the small-scale on-site electricity production, the PV generated electricity feed-tariff rate is also considered to be increased by $3 \%, 5 \%$ and $7 \%$ respectively in the future. Extensive Retrofit packages COMB14, 15, 17 and 18, which include a number of renewable EEMs (solar PV, BIPV) have been selected to conduct such sensitivity analysis.

The investment costs, global costs and payback period for COMB 14, 15, 17 and 18 with respect to the decreasing renewable energy product price from $3 \%$ to $7 \%$ are illustrated respectively in Figure 11-13. It can be seen that the reductions for investment costs, global costs and payback periods are in the range of $1.4 \%$ to $6.2 \%, 1.5 \%$ to $2.7 \%$ and $1.9 \%$ to $7.2 \%$ respectively as the renewable energy product price reduces from $3 \%$ to $7 \%$. Among the four selected combination packages, COMB 15 is more sensitive to the changing price of renewable energy product, with the maximum $7.2 \%$ payback reduction. COMB 17 is ranked as the $2^{\text {nd }}$ most sensitive to the changing renewable energy product price, while COMB 14 and COMB 18 are less sensitive. The reason is that COMB 15 and 17 consider the full usage of the roof space for the installation of BIPV, with total area of $384 \mathrm{~m}^{2}$. While the total installed BIPV area in COMB 14 and 18 are only $240 \mathrm{~m}^{2}$. The amount of electricity generated by BIPV are higher in COMB $15 / 17$ than that in COMB14/18, which leads to greater changes in cost optimal analysis under the reduced 
417 renewable energy price. Further inspection of Figure 11-13 reveals that, although the 418 investment cost for COMB 15 is about $13.1 \%$ higher than COMB 14 , due to the contributions 419 of extra BIPV installed, the global costs and payback periods for COMB 14 and 15 are about 420 the same despite the drop in renewable energy product price. Hence, it could be concluded that 421 in the future with favourable government incentives for renewable energy, it is more cost 422 effective to install renewable energy systems to their full capacity in building retrofit projects.

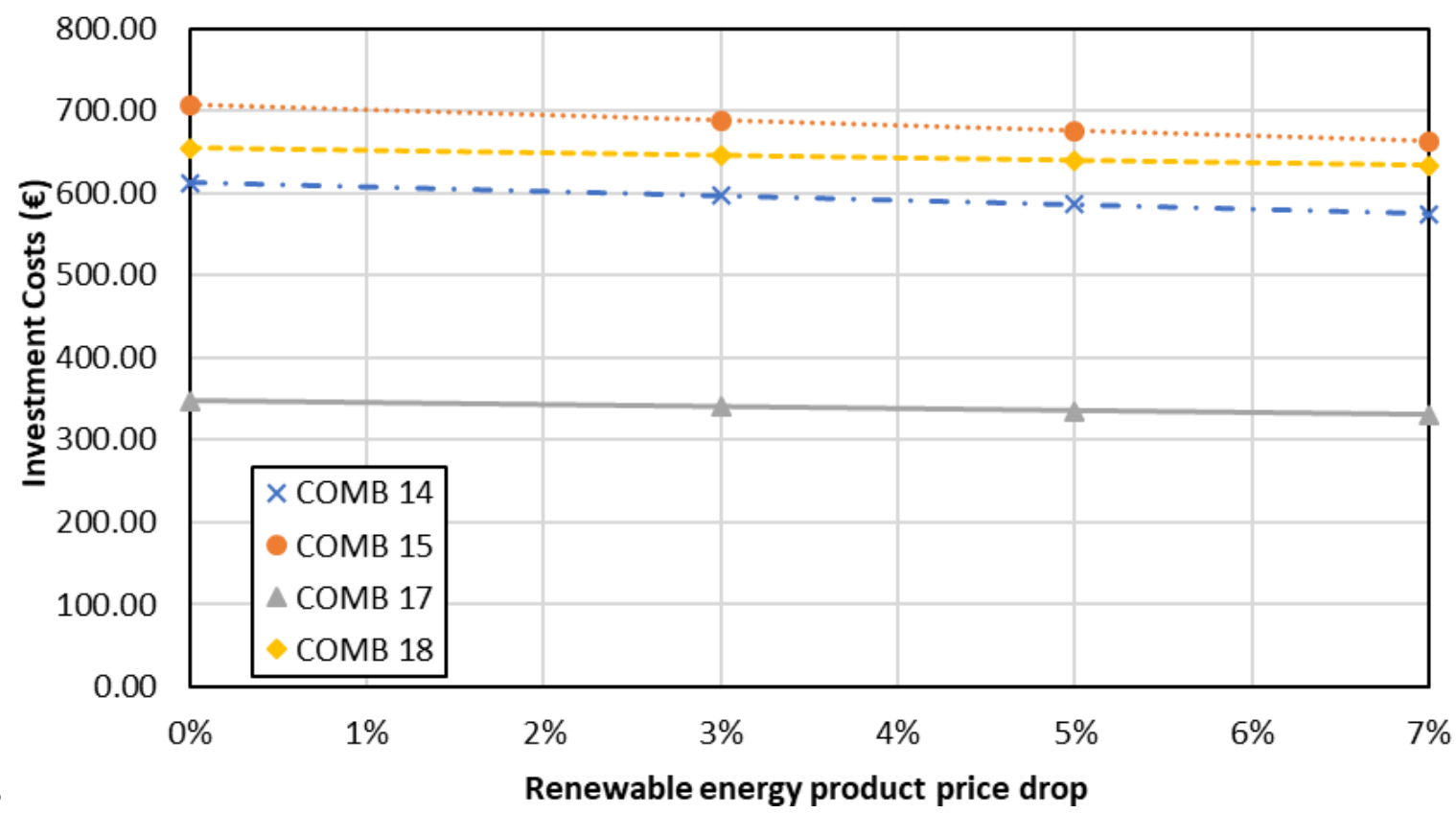

424 Figure 11 Variations of investment costs with respect to the renewable energy product price 425 drop (PV generated feed in tariff rate increased by 7\%)

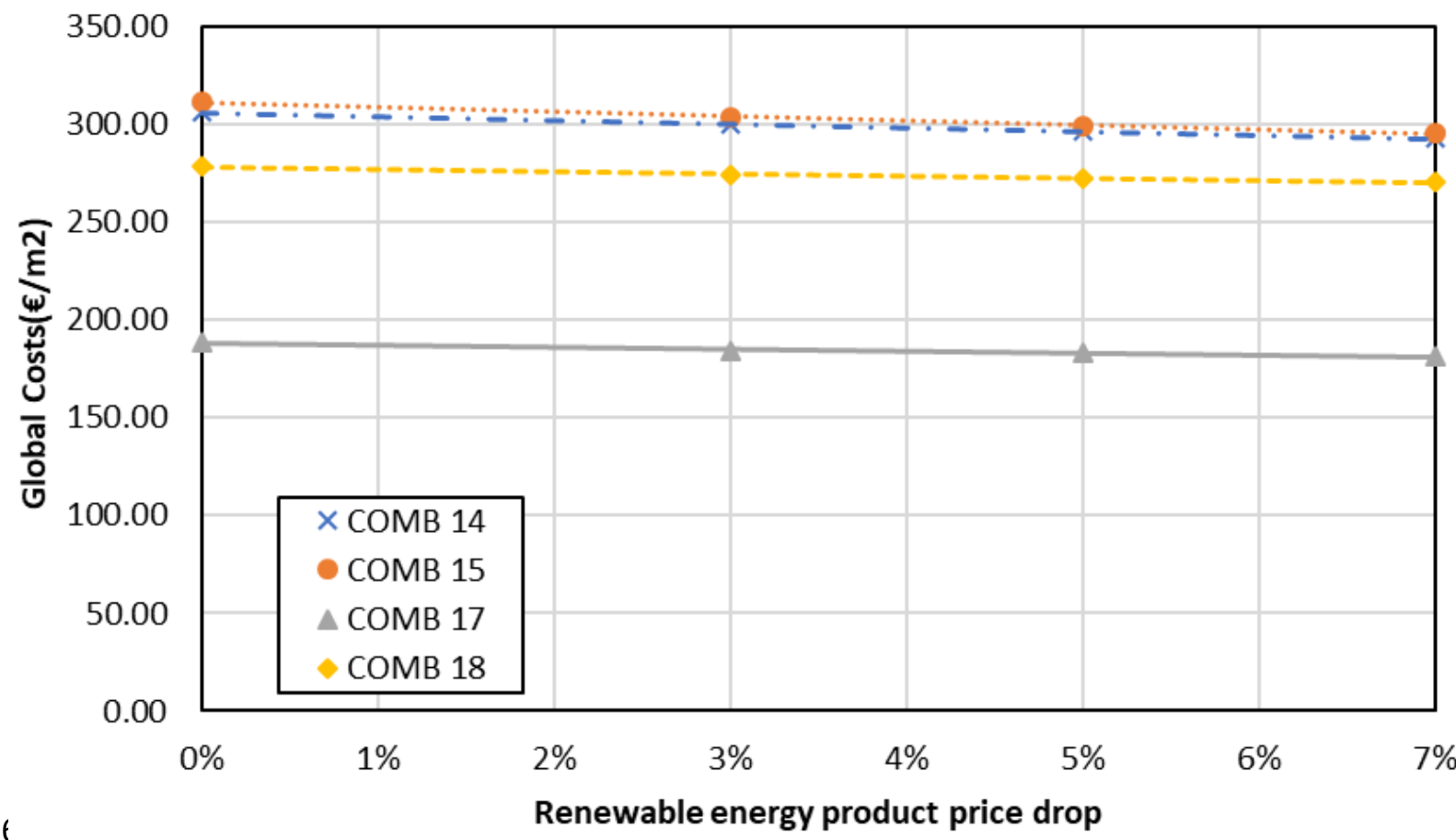


Figure 12 Variations of global costs with respect to the renewable energy price drop (PV generated feed in tariff rate increased by $7 \%$ )

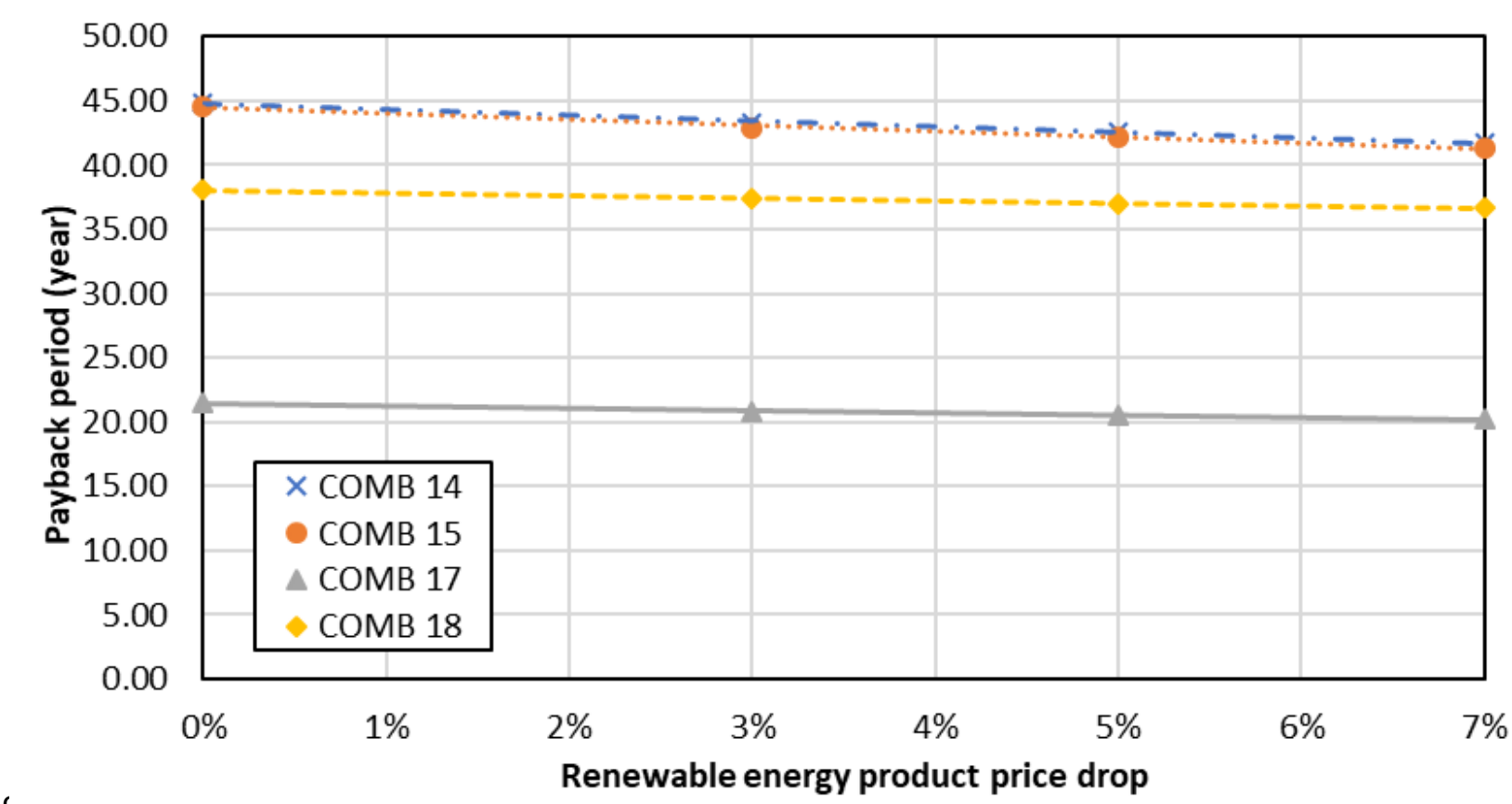

425

430

431

432

433

434

435

436

437

438

439

Figure 13 Variations of payback period with respect to renewable energy product price drop

(PV generated feed in tariff rate increased by $7 \%$ )

Table 8 indicates the influence of increasing the PV generated feed in tariff rate on the investment cost, global cost and payback period for the selected COMBs. By increasing the PV generated feed in tariff rates from 3\% to 7\%, the global cost and payback period is reduced by $0.2 \%-2.2 \%$ and $0.2 \%-1.1 \%$ respectively. Changes in PV generated feed in tariff rate will have no effect on the investment cost, due to the reason that such incentives will only be related to the annual energy utilization.

Table 8 Variations of increasing PV generated feed in tariff rate on the investment cost, global cost and payback period for selected combination packages

\begin{tabular}{|c|l|r|r|r|r|}
\hline \multirow{4}{*}{ COMBs } & $\begin{array}{l}\text { Increase of PV } \\
\text { generated feed in } \\
\text { tariff rate }\end{array}$ & $0 \%$ & $3 \%$ & $5 \%$ & $7 \%$ \\
\hline \multirow{3}{*}{ COMB14 } & Investment cost $(€)$ & 612.7 & 612.7 & 612.7 & 612.7 \\
\cline { 2 - 6 } & Global cost $\left(€ / \mathrm{m}^{2}\right)$ & 306.35 & 305.90 & 305.59 & 305.28 \\
\cline { 2 - 6 } & Payback period (year) & 44.80 & 44.67 & 44.59 & 44.51 \\
\hline \multirow{2}{*}{ COMB15 } & Investment cost $(€)$ & 706.8 & 706.8 & 706.8 & 706.8 \\
\cline { 2 - 6 } & Global cost $\left(€ / \mathrm{m}^{2}\right)$ & 312.00 & 305.90 & 305.59 & 305.28 \\
\cline { 2 - 6 } & Payback period (year) & 44.59 & 44.67 & 44.59 & 44.51 \\
\hline \multirow{2}{*}{ COMB17 } & Investment cost $(€)$ & 347.7 & 347.7 & 347.7 & 347.7 \\
\cline { 2 - 6 } & Global cost $\left(€ / \mathrm{m}^{2}\right)$ & 189.00 & 188.14 & 187.56 & 186.98 \\
\cline { 2 - 6 } & Payback period $($ year) & 21.56 & 21.46 & 21.39 & 21.33 \\
\hline COMB18 & Investment cost $(€)$ & 654.1 & 654.1 & 654.1 & 654.1 \\
\cline { 2 - 6 } & & & & & \\
\end{tabular}




\begin{tabular}{|l|l|r|r|r|r|} 
& Global cost $\left(€ / \mathrm{m}^{2}\right)$ & 278.53 & 278.07 & 277.76 & 277.46 \\
\cline { 2 - 6 } & Payback period (year) & 38.04 & 37.95 & 37.90 & 37.84 \\
\hline
\end{tabular}

\subsection{Multi-criteria assessment approach}

\subsubsection{Social analysis of the retrofit combination packages}

Apart from the energy saving, carbon emission and cost-optimal analysis performed in the previous sections, the social impacts (including "disturbance to occupants", "indoor air quality and comfort" and "building aesthetics") for the defined retrofit combination packages are also assessed based on the pre-retrofit occupancy survey. Table 8 summarizes the energy, economic, environmental and social factors for the selected 18 COMBs. In Table 8, the numerical ranking "9" stands for the most favourable and beneficial combination condition, while ranking "1" represents the most disadvantageous solution.

"Disturbance to occupants" is generally related to the EEMs that are going to involve substantial amount of construction works, which will bring various kinds of disturbances (noise, road closure, temporary power shutdown and even temporary evacuation from the flats/rooms) to the occupants during retrofit process. For the proposed COMBs in this research, such disturbances will mainly be expected from WI, BIPV and GSHP. The insulation installation (WI) will involve the temporarily evacuation of the residents from the apartments. The installation of GSHP will involve the excavation and installation of vertical boreholes/loops in close proximity to the demo site building. Therefore, in Table 8 , the social ranking for COMB 02, 03, 04, 07, 09-18 are relatively low.

"Indoor air quality and comfort" concerns have been raised by the occupants in the pre-retrofit questionnaires. About $66.3 \%$ of residents complain about the overheating problems during the winter heating season, which could be solved by installations of SP. The moisture and condensation in the kitchen and toilet space are also reported by the occupants, who are suffering from unpleasant indoor odours without proper ventilation system. Therefore, the COMBs including HR could help to improve the indoor air quality and recover the waste heat effectively. Hence, in Table 8, the social benefits for COMB 06-08, 16-18 are relatively higher due to the upgrading with SP and HR.

"Building aesthetics" is related to the EEMs that are causing changes to the existing building façade and surrounding areas. For instance, the installations of external wall insulation (WI) and BIPV/ST on the roof is posing major changes to the existing building facades. Additionally, according to the Oslo city planning regulations, retrofit interventions which cause major 

changes to building façade will need to be approved under special licences. Therefore, in Table 8, the COMBs $(02-04,13-18)$ including WI, BIPV and ST will have low social ranking.

\subsubsection{Multi-criteria assessment taking into account of various stakeholders' preferences}

Retrofit projects involve various stakeholders (occupants, landlords, local planning authority, policy makers) who play important roles during the retrofit decision making process. Using the RezBuild project as an example, the three demo site project leaders (OBOS Ltd.- Norway, Comunidad de Madrid- Spain and Officinae Verdi Spa-Italy) work closely with the occupants to collect pre-retrofit survey results, with the aim to understand the occupants' demands and concerns (indoor air quality and comforts, less disturbance during retrofit construction process, reduced annual energy bills) during the retrofit process. The demo site leaders actually act as the project coordinators who also liaise with the local governments for obtaining additional building planning permissions. During this process, the local government will express their attitudes specially related to the construction plan, maintaining historical aesthetics of the building and reducing the disturbance to local communities. The policy makers at the national government level will specifically focus on the impacts of energy saving/carbon reduction potentials and renewable EEMs implemented, which can serve as important guidance for other similar building retrofit projects. The landlords will take part in the decision making process, with special emphasis on the changes to the building layouts/structures, long term energy saving and associated costs/payback period.

In order to capture various stakeholders' preferences for the proposed retrofit EEMs and combination packages, the "lessons learned" online survey covering a wide range of questions from multi-criteria perspectives (energy, economic, environmental and social) was designed and distributed within RezBuild project partners and their clients, who represent a wide range of stakeholders (occupants, landlords, local government, designer, project manager, etc). Based on the collected 38 copies of survey, the weighting factors (in the range of $0-1$ ) representing various stakeholders' preferences are summarized in Table 10. Higher weighting factor value means that the stakeholders express special attentions in this respect.

Finally, with the aim to provide numerical ranking for the proposed COMBs from multi-criteria and in the meantime reflecting various stakeholders' perspective, the energy, economic, environmental and social ranking factor (EEES) has been defined as the sum of the multiplications between the various multi-criteria factors and the relevant weighting factors. EEES can be calculated using following equation):

$E E E S_{i}=\sum\left(M C_{j} \times W_{k}\right)$ 
504 Where $M C_{j}$ represents the multi-criteria factors, which can be obtained from Table 9. $W_{k}$ is the 505 weighting factors shown in Table 10. The subscript " $i$ " indicates the various stakeholders' 506 pespectives. For instance, the EEES ranking value for occupants' perspective on COMB01 507 could be calculated as: $2 * 0.8+7 * 0.2+3 * 0.2+4 * 0.4+9 * 0.8+5 * 0.8+9 * 0.5=20.9$. In this way, the 508 proposed 18 COMBs have been ranked using EEES factor and illustrated in Figure 14. It is 509 obvious that COMB 05, 06 are ranked as the most favourable solutions for 3 typical 510 stakeholders (occupants, landlords and local government). This is followed by "Moderate 511 Retrofit-III" (COMB 09-12), with EEES ranking averagely 13.2\% less than COMB05/06. The 512 3rd highest EEES ranking is "Extensive Retrofit", which involves more renewable EEMS.

513 COMB 03/04 are ranked as the most unfavourable ones, which agrees well with the 514 aforementioned results obtained using Norwegian Passive house EPC grade. Using this multi515 criteria assessment approach, the various stakeholders' preferences could be numerically 516 quantified from energy, environmental, economic and social perspectives. This multi-criteria 517 assessment approach provides an easy and user-accessible tool which significantly facilitates 518 the retrofit decision-making process with wider stakeholders' engagement.

519 Table 9 Multi-criteria factors for various COMBs from energy, economic, environmental and 520 social aspects

\begin{tabular}{|c|c|c|c|c|c|c|c|c|}
\hline \multirow[b]{2}{*}{$\begin{array}{l}\text { Retrofit } \\
\text { Level }\end{array}$} & \multirow[b]{2}{*}{$\begin{array}{c}\text { Combination } \\
\text { Package } \\
\text { (COMB) }\end{array}$} & \multirow{2}{*}{$\begin{array}{c}\begin{array}{c}\text { Energy } \\
\text { factor }\end{array} \\
\text { Primary } \\
\text { Energy } \\
\text { Reduction }\end{array}$} & \multicolumn{2}{|c|}{ Economic factor } & \multirow{2}{*}{$\begin{array}{c}\text { Environmental } \\
\text { factor } \\
\\
\text { Carbon } \\
\text { Emission } \\
\text { Reduction }\end{array}$} & \multicolumn{3}{|c|}{ Social factor } \\
\hline & & & $\begin{array}{c}\text { Global } \\
\text { Costs }\end{array}$ & $\begin{array}{c}\text { Payback } \\
\text { Period }\end{array}$ & & $\begin{array}{l}\text { Disturbance } \\
\text { to } \\
\text { Occupants }\end{array}$ & $\begin{array}{l}\text { Indoor } \\
\text { Air } \\
\text { Quality } \\
\text { and } \\
\text { Comfort }\end{array}$ & $\begin{array}{l}\text { Building } \\
\text { Aesthetics }\end{array}$ \\
\hline \multirow{4}{*}{$\begin{array}{l}\text { Moderate } \\
\text { Retrofit-I }\end{array}$} & COMB01 & 2 & 7 & 3 & 4 & 9 & 5 & 9 \\
\hline & COMB02 & 2 & 7 & 3 & 3 & 3 & 5 & 6 \\
\hline & COMB03 & 2 & 3 & 1 & 3 & 3 & 4 & 6 \\
\hline & COMB04 & 2 & 3 & 2 & 4 & 3 & 6 & 6 \\
\hline \multirow{4}{*}{$\begin{array}{c}\text { Moderate } \\
\text { Retrofit- } \\
\text { II }\end{array}$} & COMB05 & 3 & 9 & 8 & 5 & 9 & 7 & 9 \\
\hline & COMB06 & 3 & 9 & 9 & 5 & 9 & 8 & 9 \\
\hline & COMB07 & 4 & 2 & 2 & 6 & 2 & 8 & 6 \\
\hline & COMB08 & 4 & 9 & 8 & 6 & 8 & 9 & 6 \\
\hline \multirow{3}{*}{$\begin{array}{c}\text { Moderate } \\
\text { Retrofit- } \\
\text { III }\end{array}$} & COMB09 & 6 & 9 & 7 & 7 & 6 & 6 & 6 \\
\hline & COMB10 & 4 & 4 & 6 & 6 & 7 & 6 & 8 \\
\hline & COMB11 & 4 & 7 & 6 & 6 & 6 & 5 & 8 \\
\hline
\end{tabular}




\begin{tabular}{|c|c|c|c|c|c|c|c|c|} 
& COMB12 & 5 & 7 & 6 & 8 & 5 & 7 & 8 \\
\hline \multirow{5}{*}{$\begin{array}{c}\text { Extensive } \\
\text { Retrofit }\end{array}$} & COMB13 & 6 & 6 & 5 & 8 & 4 & 7 & 5 \\
\cline { 2 - 10 } & COMB14 & 7 & 3 & 3 & 8 & 3 & 7 & 3 \\
\cline { 2 - 10 } & COMB15 & 7 & 3 & 3 & 6 & 4 & 7 & 3 \\
\cline { 2 - 10 } & COMB17 & 7 & 7 & 4 & 8 & 2 & 9 & 4 \\
\cline { 2 - 10 } & COMB18 & 9 & 4 & 4 & 9 & 1 & 9 & 3 \\
\hline
\end{tabular}

521

522

Table 10 Weighting factors representing various stakeholders' preferences

\begin{tabular}{|c|c|c|c|c|}
\hline \multicolumn{2}{|c|}{ Weighting factor } & Occupants & Landlords & $\begin{array}{c}\text { Local } \\
\text { government }\end{array}$ \\
\hline Energy & $\begin{array}{c}\text { Primary Energy } \\
\text { Reduction }\end{array}$ & 0.8 & 0.6 & 0.6 \\
\hline Economic & Global Costs & 0.2 & 0.8 & 0.6 \\
\cline { 2 - 5 } & Payback Period & 0.2 & 0.8 & 0.6 \\
\hline Environmental & $\begin{array}{c}\text { Carbon Emission } \\
\text { Reduction }\end{array}$ & 0.4 & 0.4 & 0.8 \\
\hline Social & $\begin{array}{c}\text { Disturbance to } \\
\text { Occupants }\end{array}$ & 0.8 & 0.5 & 0.8 \\
\cline { 2 - 5 } & $\begin{array}{c}\text { Indoor Air Quality } \\
\text { and Comfort }\end{array}$ & 0.8 & 0.6 & 0.6 \\
\cline { 2 - 5 } & Building Aesthetics & 0.5 & 0.8 & 0.8 \\
\hline
\end{tabular}

523

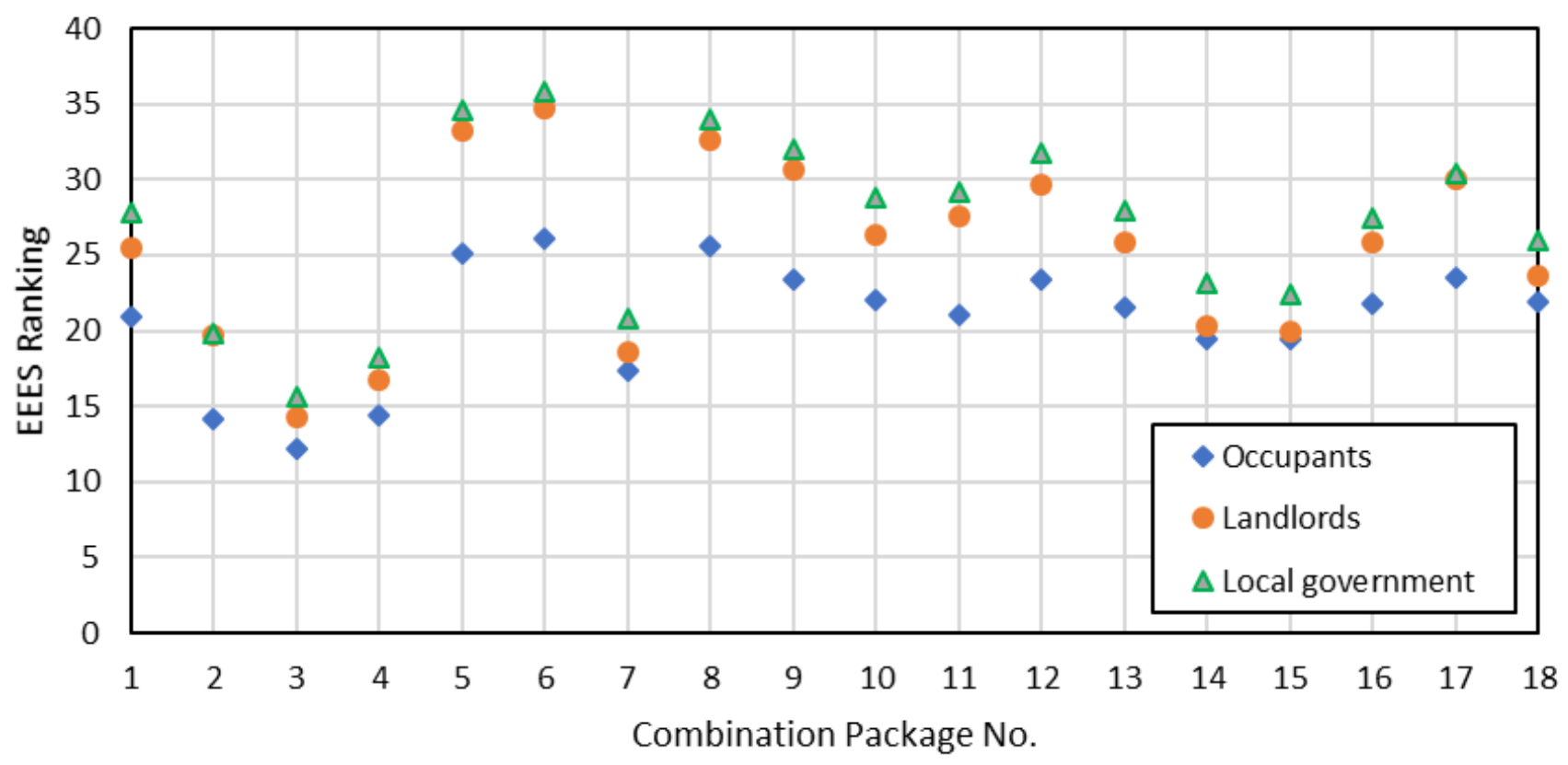

Figure 14 EEES rankings for the proposed combination packages from different 
530 This paper presents a multi-criteria assessment approach for a wide range of energy efficient measure combinations applied for a residential building retrofit constructed in 1990s in Norway. A number of energy efficient measures (EEMs) have been selected and identified into

533 three types (passive, active and renewable EEMs). Base on the level of energy saving potentials, 534 these EEMs have been combined into 18 retrofit combination packages and grouped into various retrofit levels (Moderate Retrofit-I, II, III and Extensive Retrofit). The annual primary energy consumptions (heating, hot water and electricity) for the selected combination packages are simulated in IESVE software. A multi-criteria assessment approach featuring two levels of assessments: i) combined energy, economic and environmental assessments; ii) social assessment from various stakeholders' perspective was then adopted. This approach not only presents a comprehensive overview for the selected combinations packages taking into account

541 of energy, economic and environmental saving potentials, but also quantifies different 542 stakeholders' perspectives on the proposed combination packages, which enables wider 543 engagement from various stakeholders in the retrofit decision making process. The following 544 conclusions could be drawn from this research, which are valid for similar apartment building 545 blocks insulated according to the standard of 1990's and typically in the countries situated in 546 the cold climate zones.

547 At the first level, the comprehensive assessments of the proposed combination packages on the 548 primary energy consumption, global costs and carbon reduction were conducted. It can be 549 concluded that i) Increasing the numbers of EEMs in COMBs does not necessarily leads to 550 better building performance from energy, economic and environmental point of view. 551 "Moderate Retrofit II", which mostly includes 1 passive measure with 1-3 active measures, 552 demonstrates the lowest global costs and payback period, with primary energy reduction and 553 carbon emission ranked 4th among all the retrofit COMBs. ii) "Moderate Retrofit III" ranks 554 2nd and 3rd from economical and energy/environmental points of view. This group of COMBs 555 can be selected if the investment budget is not high enough to afford "Extensive Retrofit" 556 COMBs, while the requirements of carbon reduction are still demanding. iii) "Extensive 557 Retrofit" generally lead to lowest energy consumption and lowest equivalent carbon emission, 558 with highest percentage of energy reduction compared with baseline building scenario. 559 However, these COMBs are not economically feasible, due to the long payback period and 560 great amount of global costs.

561 At the second level, the social assessment survey was conducted with the aim to generate a 562 matrix of weighting factors in order to represent various stakeholders' views on the selected 563 COMBs. The energy, economic, environmental and social ranking factor (EEES) is calculated 564 as the sum of the total multiplications between the various factors and the relevant weighting 

factors. Using such multi-criteria assessment approach, COMB05 \& 06 (within "Moderate Retrofit-II") have been ranked and chosen as the most favourable retrofit solutions, with EEES value equals to 25.6 from typical stakeholders perspectives.

Due to the development of advanced materials and manufacturing process, the investment costs for renewable EEMs could be substantially reduced in the long term. The impacts of changing renewable energy prices and PV generated feed in tariff rates on the global costs, carbon reductions and primary energy consumptions, which have rarely been analysed in literature, are numerically investigated in this research. For "Extensive Retrofit", 3\% to 7\% reduction of prices for renewable energy products will lead up to $6.2 \%, 2.7 \%$ and $7.2 \%$ reductions respectively in investment costs, global costs and payback periods. It is more cost effective to equip the renewable energy measures to their full capacity, which offers lower global costs and shorter payback period.

With no dependences on fossil fuels and therefore environmental friendly features, the implementations of renewable energy are greatly recommended by the European Commission with further supports from national level government renewable incentives. Thus, in the future, the "Extensive Retrofit" proposed in this research, could lead to higher level of primary energy reduction and carbon footprint reduction. Additionally, the cost optimal analysis performed in this research has only considered the Norwegian government feed-in tariff incentives for solar PV. The other two renewable EEMs including ST and GSHP, are expected to receive more financial supports within EU, leading to dramatic market penetration and price reduction. Therefore, in the long term, Extensive Retrofits could become more affordable and cost effective.

\section{Acknowledgement}

The authors would like to acknowledge the financial support and contributions from European Commission Horizon 2020 project RezBuild (project contract number: 768623) and project partners' contributions.

\section{Reference}

1. IPCC, Special Report on Global Warming of $1.5^{\circ} \mathrm{C}$ (SR15). 2018.

2. 773, E.C., A Clean Planet for all A European strategic long-term vision for a prosperous, modern, competitive and climate neutral economy. 2018.

3. Johansson, T., T. Olofsson, and M. Mangold, Development of an energy atlas for renovation of the multifamily building stock in Sweden. Applied Energy, 2017. 203: p. 723-736.

4. (IEA), I.E.A., World energy outlook special report: redrawing the energy-climate map. 2014. 
5. Sandberg, N.H., et al., Dynamic building stock modelling: Application to 11 European countries to support the energy efficiency and retrofit ambitions of the EU. Energy and Buildings, 2016. 132: p. 26-38.

6. Wilson, C., H. Pettifor, and G. Chryssochoidis, Quantitative modelling of why and how homeowners decide to renovate energy efficiently. Applied Energy, 2018. 212: p. 1333-1344.

7. Rosenow, J., et al., Unlocking Britain's first fuel: the potential for energy savings in UK housing. UK Energy and Research Center, 2017.

8. Patiño-Cambeiro, F., et al., Economic appraisal of energy efficiency renovations in tertiary buildings. Sustainable Cities and Society, 2019. 47: p. 101503.

9. Jermyn, D. and R. Richman, A process for developing deep energy retrofit strategies for single-family housing typologies: Three Toronto case studies. Energy and Buildings, 2016. 116: p. 522-534.

10. Tadeu, S., et al., Energy retrofit of historic buildings: Environmental assessment of cost-optimal solutions. Journal of Building Engineering, 2015. 4: p. 167-176.

11. Ciulla, G., A. Galatioto, and R. Ricciu, Energy and economic analysis and feasibility of retrofit actions in Italian residential historical buildings. Energy and Buildings, 2016. 128: p. 649-659.

12. Tetlow, D., et al., Cellulosic-crystals as a fumed-silica substitute in vacuum insulated panel technology used in building construction and retrofit applications. Energy and Buildings, 2017. 156: p. 187-196.

13. Wang, X., et al., Improving benefit-cost analysis to overcome financing difficulties in promoting energy-efficient renovation of existing residential buildings in China. Applied Energy, 2015. 141: p. 119-130.

14. Alev, Ü., et al., Renovation alternatives to improve energy performance of historic rural houses in the Baltic Sea region. Energy and Buildings, 2014. 77: p. 58-66.

15. Murray, S.N., B. Rocher, and D.T.J. O'Sullivan, Static Simulation: A sufficient modelling technique for retrofit analysis. Energy and Buildings, 2012. 47: p. 113-121.

16. Dodoo, A., L. Gustavsson, and U.Y.A. Tettey, Final energy savings and costeffectiveness of deep energy renovation of a multi-storey residential building. Energy, 2017. 135: p. 563-576.

17. Kuusk, K., T. Kalamees, and M. Maivel, Cost effectiveness of energy performance improvements in Estonian brick apartment buildings. Energy and Buildings, 2014. 77: p. 313-322.

18. Liu, L., P. Rohdin, and B. Moshfegh, LCC assessments and environmental impacts on the energy renovation of a multi-family building from the 1890s. Energy and Buildings, 2016. 133: p. 823-833.

19. Bonakdar, F., A. Sasic Kalagasidis, and K. Mahapatra, The Implications of Climate Zones on the Cost-Optimal Level and Cost-Effectiveness of Building Envelope Energy Renovation and Space Heat Demand Reduction. Buildings, 2017. 7(2): p. 39.

20. Şahin, C.D., et al., A transdisciplinary approach on the energy efficient retrofitting of a historic building in the Aegean Region of Turkey. Energy and Buildings, 2015. 96: p. 128-139.

21. Ascione, F., et al., Multi-objective optimization of the renewable energy mix for a building. Applied Thermal Engineering, 2016. 101: p. 612-621.

22. Ascione, F., et al., Energy retrofit of an educational building in the ancient center of Benevento. Feasibility study of energy savings and respect of the historical value. Energy and Buildings, 2015. 95: p. 172-183.

23. Nicolae, B. and B. George-Vlad, Life cycle analysis in refurbishment of the buildings as intervention practices in energy saving. Energy and Buildings, 2015. 86: p. 74-85. 
650

651

652

653

654

655

656

657

658

659

660

661

662

663

664

665

666

667

668

669

670

671

672

673

674

675

676

677

678

679

680

681

682

683

684

685

686

687

688

689

690

691

692

693

694

695

696

697

698

24. Ascione, F., et al., Design the refurbishment of historic buildings with the costoptimal methodology: The case study of a XV century Italian building. Energy and Buildings, 2015. 99: p. 162-176.

25. Ascione, F., et al., Multi-stage and multi-objective optimization for energy retrofitting a developed hospital reference building: A new approach to assess costoptimality. Applied Energy, 2016. 174: p. 37-68.

26. Directive 2010/31/EU of 19 May 2010 on the energy performance of buildings. European Commission 2010/31/EU (EPBD), 2010.

27. López, C.S.P. and F. Frontini, Energy Efficiency and Renewable Solar Energy Integration in Heritage Historic Buildings. Energy Procedia, 2014. 48: p. 1493-1502.

28. Eicker, U., E. Demir, and D. Gürlich, Strategies for cost efficient refurbishment and solar energy integration in European Case Study buildings. Energy and Buildings, 2015. 102: p. 237-249.

29. Gürlich, D., A. Dalibard, and U. Eicker, Photovoltaic-thermal hybrid collector performance for direct trigeneration in a European building retrofit case study. Energy and Buildings, 2017. 152: p. 701-717.

30. Evola, G. and G. Margani, Renovation of apartment blocks with BIPV: Energy and economic evaluation in temperate climate. Energy and Buildings, 2016. 130: p. 794810.

31. de Santoli, L., et al., Building integrated bioenergy production (BIBP): Economic sustainability analysis of Bari airport CHP (combined heat and power) upgrade fueled with bioenergy from short chain. Renewable Energy, 2015. 81: p. 499-508.

32. Lo Basso, G., et al., Hybrid systems adoption for lowering historic buildings PFEC (primary fossil energy consumption) - A comparative energy analysis. Renewable Energy, 2018. 117: p. 414-433.

33. Sharafi, M., T.Y. EIMekkawy, and E.L. Bibeau, Optimal design of hybrid renewable energy systems in buildings with low to high renewable energy ratio. Renewable Energy, 2015. 83: p. 1026-1042.

34. Nižetić, S., et al., Hybrid energy scenarios for residential applications based on the heat pump split air-conditioning units for operation in the Mediterranean climate conditions. Energy and Buildings, 2017. 140: p. 110-120.

35. Davis, K., A method to measure success dimensions relating to individual stakeholder groups. International Journal of Project Management, 2016. 34(3): p. 480-493.

36. ARTOLA, I., Boosting Building Renovation: What potential and value for Europe? 2016, European Parliament.

37. Shao, Y., P. Geyer, and W. Lang, Integrating requirement analysis and multi-objective optimization for office building energy retrofit strategies. Energy and Buildings, 2014. 82: p. 356-368.

38. Araújo, C., et al., Cost-benefit analysis method for building solutions. Applied Energy, 2016. 173: p. 124-133.

39. Arumägi, E. and T. Kalamees, Analysis of energy economic renovation for historic wooden apartment buildings in cold climates. Applied Energy, 2014. 115: p. 540-548.

40. Niemelä, T., R. Kosonen, and J. Jokisalo, Energy performance and environmental impact analysis of cost-optimal renovation solutions of large panel apartment buildings in Finland. Sustainable Cities and Society, 2017. 32: p. 9-30.

41. https://rezbuildproject.eu/. 2017-2021.

42. SSB 2018b - Statistisk Sentralbyrå (Statistics Norway) table 06265 "Dwellings by type of building". Accessed 6.12.2018; Available from:

https://www.ssb.no/statbank/table/06265/. 
43. BERTRAMJORDET ertramjordet borettslag-Ditt hjem. Available from: http://www.bertramjordet.no/for-deg-som-har-lyst-til-a-flytte-hit/velkommen-tilbertramjordet-borettslag/.

44. OBOS. Available from: https://www.obos.no/.

45. Castleton, H.F., et al., Green roofs; building energy savings and the potential for retrofit. Energy and Buildings, 2010. 42(10): p. 1582-1591.

46. Hong, T., J. Kim, and C. Koo, LCC and LCCO2 analysis of green roofs in elementary schools with energy saving measures. Energy and Buildings, 2012. 45: p. 229-239.

47. REZBUILD Project. 2019 [cited 2019 April]; Available from: https://rezbuildproject.eu/.

48. Bodgan Atanasiu, I.K., Implementing the cost-optimal methodology in EU countriesLessons learned from case studies. The building performance Insitute Europe BPIE, 2013.

49. Byggteknisk forskrift (TEK17), in Veiledning om tekniske krav til byggverk. 2017.

50. Saint-Gobain, A Design Guide to Part L: 2013. February 2014.

51. Sealants, C.; Available from: http://www.casteleinsealants.be/.

52. Standard 55-2013 -- Thermal Environmental Conditions for Human Occupancy. 2013, ANSI/ASHRAE.

53. 14511-3, E., Air conditioners, liquid chilling packages and heat pumps with electrically driven compressors for space heating and cooling - Part 3: Test methods. 2007.

54. Standardization], C.E.C.f., Energy performance of buildings - Economic evaluation procedure for energy systems in buildings. Standard EN15459:2007, Brussels: CEN, 2007.

55. Lien, K.M., CO2 emissions from Biofuels and District Heating in Zero Emission Buildings (ZEB). The Research Center on Zero Emission Buildings 2013 ZEB Project report, 2013.

56. William Steinhurst, Patrick Knight, and M. Schultz, Hydropower Greenhouse Gas Emissions - State of the Research, 14, Synapse, Energy Economics, Inc, Cambridge, MA. Synapse, Energy Economics, Inc, Cambridge, MA (2012), 2012.

57. Hastings, R., Lessons from Exemplary Housing Renovations. Solar heating \& cooling programme international energy agency, 2010 May.

58. Commission, E., Guidelines accompanying Commission Delegated Regulation (EU) No 244/2012 supplementing Directive 2010/31/EU by establishing a comparative methodology framework for calculating cost-optimal levels of minimum energy performance requirements for buildings and building elements. Official Journal of the European Union, 2012: p. 1-28.

59. Kurnitski, J., Cost Optimal and Nearly Zero-Energy Buildings (nZEB): Definitions, Calculation Principles and Case Studies. Green Energy and Technology, 2013.

60. Thullner, K., Low-energy buildings in Europe - Standards, Criteria and consequences, in A study of nine European countries. 2010.

61. Salata, F., et al., Heading towards the nZEB through CHP+HP systems. A comparison between retrofit solutions able to increase the energy performance for the heating and domestic hot water production in residential buildings. Energy Conversion and Management, 2017. 138: p. 61-76.

62. Commission, E., Directive 2010/31/EU of the European Parliament on the Energy Performance of Buildings. 2010.

63. European Commission guidance for renewables support schemes. 2013. Brussels, 5.11.2013 